\title{
Defining lipid mediators of insulin resistance: controversies and challenges
}

\author{
Louise K Metcalfe, Greg C Smith and Nigel Turner \\ Department of Pharmacology, School of Medical Sciences, UNSW Sydney, New South Wales, Australia \\ Correspondence should be addressed to N Turner: n.turner@unsw.edu.au
}

\begin{abstract}
Essential elements of all cells - lipids - play important roles in energy production, signalling and as structural components. Despite these critical functions, excessive availability and intracellular accumulation of lipid is now recognised as a major factor contributing to many human diseases, including obesity and diabetes. In the context of these metabolic disorders, ectopic deposition of lipid has been proposed to have deleterious effects on insulin action. While this relationship has been recognised for some time now, there is currently no unifying mechanism to explain how lipids precipitate the development of insulin resistance. This review summarises the evidence linking specific lipid molecules to the induction of insulin resistance, describing some of the current controversies and challenges for future studies in this field.

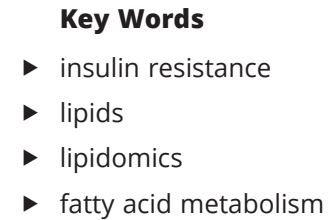

Journal of Molecular Endocrinology (2019) 62, R65-R82
\end{abstract}

\section{Insulin resistance and lipid metabolism}

Obesity and diabetes are metabolic conditions of increasingly widespread significance to modern populations. The global scale and gravity of their impacts on general health, life expectancy and quality of life encourage the search for new treatment options. Mechanisms which promote, instigate or maintain these disorders are complex, interrelated and certainly not simple to define. Both obesity and diabetes are, however, known to be underpinned by insulin resistance (IR), and study into this condition is hoped to elucidate pathways with therapeutic potential.

The circulating hormone insulin regulates substrate movement into tissues for either oxidation or storage. Its many activities, both stimulatory and inhibitory, are implemented via a complex signalling pathway activated by the insulin receptor (Saltiel \& Kahn 2001, Taniguchi et al. 2006, Humphrey et al. 2013). Of particular relevance to diabetes onset is insulin stimulation of glucose uptake and metabolism, as well as fatty acid (FA) metabolism; the non-adipose tissues most essential in these processes are muscle and liver. Tissue desensitisation to insulin, and the resultant failure of a normal insulin dose to elicit these responses, is known as IR. Although incompletely defined, a number of different mechanisms have been proposed to promote the development of IR, including overproduction of reactive oxygen species, dysfunction of mitochondria, induction of ER stress and activation of inflammatory pathways (Donath \& Shoelson 2011, Gregor \& Hotamisligil 2011, Tiganis 2011, Kim et al. 2015, Montgomery \& Turner 2015, Rocha et al. 2016). Another factor that is strongly associated with IR is the accumulation of bioactive lipids in non-adipose tissues (Kraegen et al. 1991, Summers 2006, Chavez \& Summers 2012, Turner et al. 2013, Bellini et al. 2015).

While unlimited access to calorie-dense foods and reductions in physical activity create an environment conducive to excessive lipid accumulation, there are various factors at the cellular level that heighten lipid 
accumulation in non-adipose tissues, with alterations to adipose tissue function/metabolism that occur during obesity thought to be intimately involved. Hypertrophic and hyperplasic responses both expand adipose storage capacity in apparent direct compensation upon lipid accumulation. Such increases in adipocyte size and number are also proven, however, to independently predict the development of IR. Controlled for BMI, insulinresistant individuals have been found to possess a greater proportion of small adipose cells than do insulin-sensitive individuals, while their large adipose cells are fewer but larger (Weyer et al. 2000, McLaughlin et al. 2007, Johannsen et al. 2014, McLaughlin et al. 2014, Kim et al. 2015). Moreover, adipogenesis is impaired with IR (Deurenberg et al. 1991, Yang et al. 2004, McLaughlin et al. 2007, 2014) and promotion of adipocyte differentiation improves insulin sensitivity (De Souza et al. 2001, McLaughlin et al. 2010, Eliasson et al. 2014). Taken together, such findings tie IR to stunted expandability of adipose tissue, and a corresponding overspill of lipids from overloaded adipose depots into insulin-sensitive peripheral tissues such as skeletal muscle and liver.

At the level of tissues such as muscle and liver, intracellular lipid accumulation is logically caused by either heightened uptake, diminished utilisation and for some tissues enhanced lipogenesis. Rodent models have demonstrated that muscle- and liver-specific overexpression of the lipid hydolysis enzyme, lipoprotein lipase (LPL) leads to selective lipid accumulation and IR in the respective tissues (Kim et al. 2001). In contrast muscle-specific deletion of LPL results in improved insulin sensitivity in muscle, but impaired insulin action in liver and other tissues (Wang et al. 2009). Whole-body deletion of fatty acid transport protein FATP1 protects against the development of IR in skeletal muscle (where it is highly expressed) (Kim et al. 2004a), while viral-mediated hepatic deletion of FATP2 or FATP5 protects against hepatic steatosis and glucose intolerance, although how modulating these transporters in liver influenced insulin action in other tissues was not assessed (Doege et al. 2008, Falcon et al. 2010). These findings are not without their contradictions: the overexpression of FATP1 in skeletal muscle, for example, channels lipids to oxidation and does not predispose to diet-induced IR (Holloway et al. 2011). Overexpression of the FA transporter/scavenger receptor CD36 in muscle and liver has also been shown to attenuate genetic and diet-induced IR via enhancement of oxidative capacity (Ibrahimi et al. 1999, HéronMilhavet et al. 2004, Garbacz et al. 2016).
On the other side of the equation, involvement of mitochondrial fatty acid oxidation (FAO) in aberrant lipid accumulation is somewhat more complex. Correlative studies have shown defective mitochondrial markers in insulin-resistant skeletal muscle (Kelley et al. 2002, Mootha et al. 2003, Patti et al. 2003, Petersen et al. 2003, Ritov et al. 2005). Yet despite this seemingly plausible association, lipid excess is also seen to enhance mitochondrial oxidative capacity (Turner et al. 2007, Hancock et al. 2008, Koves et al. 2008). Genetic mitochondrial dysfunction in mice also presents contradictory evidence: long-chain acylCoA dehydrogenase deficiency leads to hepatic IR (Zhang et al. 2007); while defective mitochondrial substrate metabolism induced by deletion of mitochondrial transcription factor A (TFAM), apoptosis inducing factor (AIF), very long-chain acyl-CoA dehydrogenase (VLCAD) or carnitine palmitoyltransferase 2 (CPT2) protects from diet-induced obesity and IR (Wredenberg et al. 2006, Pospisilik et al. 2007, Zhang et al. 2010). These discrepancies may well reflect homeostatic compensatory mechanisms responding to either elevated lipid availability or dysfunctional mitochondria (Turner et al. 2007, Serup et al. 2016). Apparent regulatory redundancies suggest the biological relevance of mitochondrial FAO, regardless of whether its deterioration is a consequence or stimulus of lipid accumulation. The correlations between lipid accumulation and IR appear to be due not to changes in either lipid uptake or FAO alone, but likely a combination of the two, which ultimately leads to the aberrant build-up of different classes and species of lipids that have deleterious effects on insulin action.

\section{The complexity of the lipidome}

Lipids have well-defined roles in signalling and gene transcription, as metabolic fuels and as structural components of cells. The number of distinct chemical entities in the lipidome is not completely resolved. The combination of various backbones, headgroups and acyl chains gives rise to many thousands of lipids that are classified in distinct classes, subclasses and subgroups (Li et al. 2015, Lydic \& Goo 2018). This diversity in chemical structure results in a vast spectrum of physiochemical properties across various lipids, necessitating different methods and strategies for quantification (Shevchenko \& Simons 2010, Li et al. 2015, Lydic \& Goo 2018). Not all lipid species have been implicated in the development of IR, but we highlight below major species where a direct or indirect association has been described (Fig. 1). 


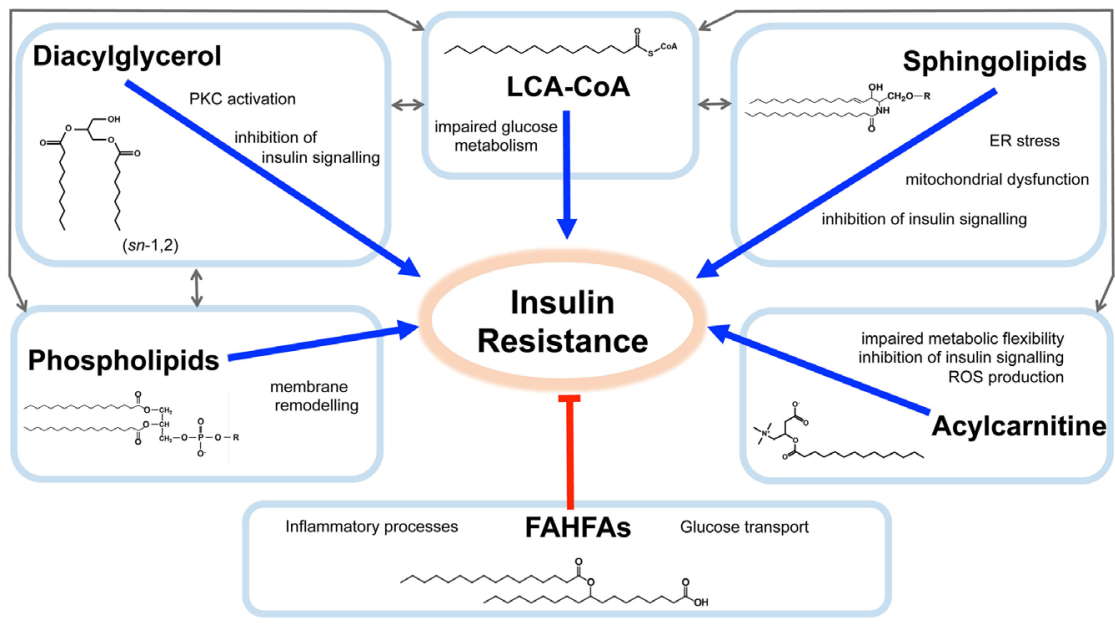

Figure 1

Lipid classes and metabolites linked with insulin resistance. Example structures of lipids within each class are shown, along with proposed mechanisms by which accumulation or depletion of these lipids is thought to induce insulin resistance. Grey lines highlight that LCA-CoAs provide fatty acyl chains for all lipid species, as well as other key conversions between lipid classes. FAHFA, branched fatty acid esters of hydroxy fatty acids; ROS, reactive oxygen species.

\section{Mediators of lipid-induced IR - many culprits for the same crime}

\section{Triglyceride}

The accumulation of triglyceride (TAG) content has long been associated with the insulin-resistant state (Storlien et al. 1991, Pan et al. 1997, Manco et al. 2000). TAG is the primary source of lipid storage within tissues and inappropriate TAG accumulation is thought to be indicative of a disturbance at some level in lipid metabolism pathways. While a frequent association between TAG and IR is observed, it should also be noted that a number of human and rodent studies have demonstrated overt disconnections. Intrahepatic and intramyocellular TAG accumulation have both been observed in the absence of IR (Goodpaster et al. 2001, Amaro et al. 2010, Visser et al. 2011, Gemmink et al. 2016, Ter Horst et al. 2017); hepatic IR has been observed in the absence of TAG accumulation (Semple et al. 2009). While TAGs are considered to be relatively benign with respect to directly causing IR, intracellular TAG synthesis and storage is a highly dynamic process, suggested to have a protective role by warding against accumulation of more lipotoxic species in muscle (Montell et al. 2001, Liu et al. 2007, Pickersgill et al. 2007, Schenk \& Horowitz 2007, Bergman et al. 2018), adipocytes (Chavez \& Summers 2003) and $\beta$-cells (Cnop et al. 2001).

Enhanced channelling of FA substrate to TAG can reduce lipotoxic pressure despite greater cellular lipid content (Listenberger et al. 2003, Coll et al. 2008, Henique et al. 2010, Capel et al. 2016). Indeed, the apparently futile, ATP-consuming cycle of FA re-esterification to TAGs during adipocyte lipolysis appears designed to protect cells from lipotoxic stress (Chitraju et al. 2017); in $\beta$-cells, this cycle may regulate insulin secretion (Corkey et al. 2000, Nolan et al. 2006, Fex \& Mulder 2008). Enhanced sequestration of TAG in cytosolic lipid droplets via perilipin protein action can blunt muscle IR, such that the greatest increase in fat storage capacity is associated with lowest reduction of insulin sensitivity (Bosma et al. 2012, Billecke et al. 2015, Gemmink et al. 2016, Shepherd et al. 2017). TAGs can therefore be considered to act as a reservoir for FFA storage, on similar principles to the larger-scale role played by adipose tissue. When the protective buffer that TAG provides is exceeded, and its storage capacity is no longer able to compensate for high lipid uptake rates, the consequent formation and accumulation of more deleterious lipid metabolites results in IR.

\section{Long-chain fatty acyl-CoA}

Long-chain fatty acyl-CoA (LCA-CoA), the initial active intermediate formed during FA metabolism, has also been implicated in the development of IR. Studies have demonstrated negative correlations between LCACoA intracellular accumulation and insulin action in the skeletal muscle of HFD-fed rodents (Oakes et al. 1997a,b, Ellis et al. 2000, Wright et al. 2011), with acute lipid infusion-based studies in rodents and humans recapitulating these associations (Tsintzas et al. 2007, Hoy et al. 2009). Impairment of insulin signalling and glucose metabolism in this context is theorised to arise, in part, via LCA-CoA interactions with proteins including protein kinase C (Færgeman \& Knudsen 1997), glycogen synthase (Wititsuwannakul \& Kim 1977), glucokinase (Tippet \& Neet 1982a,b), hexokinase (Thompson \& Cooney 2000), as well as LCA-CoA-induced alterations in gene transcription (Hertz et al. 1998). LCA-CoA can also impact insulin sensitivity through flow-on effects on FA metabolism and synthesis of other deleterious lipids 
(Fig. 1). The influence of LCA-CoAs on insulin action is speculated to better reflect acute changes in tissue lipid metabolism than other lipid molecules that arise through more chronic exposure to FA excess (Ellis et al. 2000).

\section{Acylcarnitines}

Acylcarnitines are generated during an early stage of mitochondrial FAO, converted from LCA-CoAs and carnitine via carnitine palmitoyltransferase 1 (CPT1) at the outer mitochondrial membrane before reconversion to constituent parts via CPT2 in the mitochondrial matrix. Accumulation of this lipid intermediate can often therefore serve as a measure of incomplete FAO (Van Hove et al. 1993, Koves et al. 2008, Mihalik et al. 2010, Aguer et al. 2013) and thereby also of mitochondrial energy substrate overload. Given the association of diminished FAO with IR, it is perhaps unsurprising that long-term acylcarnitine accumulation in plasma and skeletal muscle has also been presented as a feature of the condition (Ukropcova et al. 2005, Mihalik et al. 2010, Wolf et al. 2013, Aguer et al. 2015, Xiang et al. 2017). Pharmacological reduction of acylcarnitine content in a mouse model of IR has been reported to recover insulin sensitivity and reduce blood glucose levels (Liepinsh et al. 2016). An accompanying study, which heightened acylcarnitine content in mice through both acute and long-term administration of palmitoylcarnitine, saw the consequential induction of muscle-specific IR (Liepinsh et al. 2017). Regulation of metabolic flexibility, production of reactive oxygen species and inhibition of insulin signalling have all been suggested as mechanisms linking acylcarnitines with IR (Muoio et al. 2012, Aguer et al. 2015, Liepinsh et al. 2017), although it is still unclear to what extent acylcarnitines have a primary role in the induction of IR.

\section{FA esters of hydroxy-fatty acids}

A new class of endogenous lipids identified by untargeted mass spectrometry have been linked with IR. Discovered in tissues and serum of mice overexpressing the glucose transporter protein GLUT4 in adipose tissue (AG4OX mice), branched fatty acid esters of hydroxy-fatty acids (FAHFAs) consist of a series of isomeric combinations of a fatty acid and a hydroxy-fatty acid moiety (Yore et al. 2014). FAHFA levels are higher in adipose tissue and serum of the insulin-sensitive AG4OX model and are reduced in fat and serum of insulinresistant humans (Yore et al. 2014). Anti-inflammatory and insulin-sensitising effects of these lipids are proposed to be in part mediated by activation of the G-protein-coupled receptor GPR120 (Yore et al. 2014, Moraes-Vieira et al. 2016). In a similar vein, a recent study in humans reported that the adipose levels of another 'non-conventional' form of FA, monomethyl branched-chain FA (mmBCA) were responsive to weight loss and positively correlated with insulin sensitivity (Su et al. 2015).

\section{Phospholipids}

Cellular phospholipids comprise the key structural determinant of membrane biophysical properties, dictating facets of topology and fluidity. The principal components of the membrane lipid population, phosphatidylcholine (PC) and phosphatidylethanolamine (PE), have each been positively correlated with insulin sensitivity in human skeletal muscle, while the PC:PE ratio is negatively correlated (Newsom et al. 2016, Lee et al. 2017). Phospholipid species containing polyunsaturated fatty acids (PUFAs) are associated with improved insulin action, partly due to their effects on greater membrane fluidity and insulin receptor abundance (Yorek et al. 1989, Borkman et al. 1993, Pan et al. 1995, Janovská et al. 2010). The $\omega-3$ PUFA-containing phospholipids in particular are reasonably well established to benefit insulin sensitivity in rodents and humans, even in conjunction with lipid excess (Popp-Snijders et al. 1987, Fasching et al. 1991, Haugaard et al. 2006, González-Périz et al. 2009, Stephens et al. 2014). Their reduction in HFD-fed and IR conditions is seen alongside increased $\omega-6$ PUFA content, and an overall increase in phospholipid saturation (Clore et al. 2000, Smith et al. 2010, Hoeks et al. 2011, Montgomery et al. 2017). These remodelling patterns have recently been shown to be most prominent in IR-susceptible mouse strains, while being partially resisted in the IR-resistant BALB/c strain (Montgomery et al. 2017). Phospholipid remodelling is hardly confined to the context of insulin action, however, with membrane lipid composition also implicated in skeletal muscle growth and maintenance, mitochondrial biogenesis, oxidative capacity, contractile function and exercise performance (Funai et al. 2013, Selathurai et al. 2015, Funai et al. 2016). Primary or direct causal mechanisms of phospholipids in IR aetiology are not yet fully established.

\section{Diacylglycerols}

The second messenger diacylglycerol (DAG) is one of the key lipid intermediates most frequently proposed to mediate IR (Erion \& Shulman 2010, Samuel \& Shulman 2012). From the initial identifications of elevated DAG 
content in IR rat tissues (Turinsky et al. 1990), multiple subsequent studies have demonstrated correlations between DAG accumulation and impaired insulin action in various tissues in both rodents and humans (Samuel et al. 2004, 2007, Jornayvaz et al. 2011, Magkos et al. 2012). Conversely, decreases in DAG content have been associated with protection from IR (Neschen et al. 2005, Choi et al. 2007).

The prime attraction of DAG as a candidate for inducing IR is the existence of clearly defined mechanisms that have been put forward to explain its effects. DAGs have long been known to activate protein kinase C (PKC) (Hannun et al. 1986, Bishop \& Bell 1988), which in conditions of lipid overload can result in direct interference with components of the canonical insulin signalling pathway. In muscle, DAGs activate the novel PKCO and PKC $\delta$ isoforms (Itani et al. 2002, Szendroedi et al. 2014); in liver, the РКС isoform (Samuel et al. 2004, 2007, Zhang et al. 2007, Petersen et al. 2016). Consequent PKC action in these tissues prevents the normal insulin-stimulated tyrosine phosphorylation of insulin receptor substrate-1 (IRS-1), promotes inhibitory serine phosphorylation, with the net effect an inhibition of phosphorylation/activation of the downstream serine/ threonine kinase protein kinase B (Akt/PKB) (Szendroedi et al. 2014). Accordingly, ablation of PKCO protects mice from lipid-induced defects in muscle insulin signalling and glucose transport (Kim et al. 2004b), while deletion/ knockdown of PKC $\varepsilon$ ameliorates whole-body and hepatic IR in fat-fed animals (Samuel et al. 2007, Schmitz-Peiffer et al. 2007).

\section{Ceramides and sphingolipids}

Ceramide, the basic unit of all sphingolipids, is situated at a nexus of sphingolipid metabolism: converted to a myriad of other more complex sphingolipid species, which are in turn recycled back to ceramide. Lipidomic profiling suggests that ceramide accumulation in plasma, muscle, liver, adipose and/or brain strongly corresponds with development of IR (Adams et al. 2004, Straczkowski et al. 2004, Holland et al. 2007, Haus et al. 2009, Coen et al. 2010, Frangioudakis et al. 2010, Ussher et al. 2010, Longato et al. 2012, Xia et al. 2015, Luukkonen et al. 2016, Campana et al. 2018, Perreault et al. 2018). Exercise and/or weight loss interventions, improving insulin sensitivity, have also been shown to reduce ceramide content in skeletal muscle and in plasma (Dube et al. 2008, 2011, Amati et al. 2011, Bergman et al. 2015, Warshauer et al. 2015). Additionally, pharmacological and genetic interventions to reduce (whole-body) ceramide content, by inhibiting its synthesis or enhancing its downstream metabolism, improve insulin sensitivity in both humans and rodents (Holland et al. 2007, Yang et al. 2009, Ussher et al. 2010, Dekker et al. 2013, Turpin et al. 2014, Holland et al. 2017).

Mechanistically, the most convincingly demonstrated link between ceramide accumulation and the development of IR is the impairment of Akt activation. Ceramide signalling stimulates and stabilises the binding of atypical PKC $\zeta$ to Akt so that the latter kinase cannot bind phosphatidylinositol $(3,4,5)$-triphosphate $\left(\mathrm{PIP}_{3}\right)$ and consequently cannot be activated by insulin (Bourbon et al. 2000, Stratford et al. 2001, Powell et al. 2003, Fox et al. 2007). Similarly activated by ceramide is protein phosphatase $2 \mathrm{~A}$ (PP2A), which dephosphorylates and thus impairs Akt (Salinas et al. 2000, Teruel et al. 2001, Zinda et al. 2001, Chavez et al. 2003). These two inhibitory mechanisms are independent, targeting distinct protein domains. They appear to have cell type-dependent functional dominance (Bourbon et al. 2002, Stratford et al. 2004, Fox et al. 2007), but operate concurrently in at least some instances (Dey et al. 2007, Chen et al. 2017). Despite the direct link to insulin action, however, the fact that these mechanisms have been identified primarily in muscle has prompted some researchers to raise doubts as to their relevance in other tissues (Petersen \& Shulman 2017).

Less well-reported impacts on the canonical insulin signalling pathway include the inhibition of IRS-1 action via ceramide-stimulated pathways thought to include some combination of double-stranded RNA-dependent protein kinase (PKR), mixed-lineage kinase-3 (MLK3), c-Jun N-terminal kinase (JNK), the IкB kinase complex (IKK) and/or protein-tyrosine phosphatase 1B (PTP1B) (Hehner et al. 2000, Sathyanarayana et al. 2002, Kim et al. 2004, Gual et al. 2005, MohammadTaghvaei et al. 2012, Hage Hassan et al. 2016). Similarly, ceramideassociated activation of JNK and IKK is suggested to block $\mathrm{PIP}_{3}$ action via increased expression of the SH2 domaincontaining inositol 5-phosphatase 2 (SHIP2) (GorganiFiruzjaee et al. 2014). Somewhat more indirectly, altered ceramide and sphingolipid composition can promote the mislocalisation of membrane-associated proteins including the insulin receptor by disrupting membrane fluidity, curvature and microdomain (lipid raft) structure (Lasserre et al. 2008, Pewzner-Jung et al. 2010, Gao et al. 2011, Yurlova et al. 2011, Silva et al. 2012, Park et al. 2013). Ceramide accumulation may also impact hepatic lipid uptake via CD36 (Xia et al. 2015) or the inhibition of insulin-induced gene expression in $\beta$-cells (Poitout \& Robertson 2008). 
The metabolic fate of ceramides provides further potential for contribution to IR aetiology. Through (often reversible) reactions that add a variety of head-group molecules, ceramide can be converted into a diverse range of more complex sphingolipids: phosphocholine or glucose moieties, for example, giving rise to sphingomyelin or glucosylceramide respectively. Certain species of these sphingolipids have also been associated with metabolic dysfunction, particularly in studies demonstrating the beneficial effects of their deficiency. The genetic ablation of sphingomyelin synthase 2 (Sms2), for instance, has been found in HFD-fed rodents to improve whole-body insulin sensitivity, glucose tolerance and weight gain ( $\mathrm{Li}$ et al. 2011, Sugimoto et al. 2016). It has been suggested, however, that these benefits may be due partially to elevations in very-long-chain (VLC) ceramides rather than directly from sphingomyelin deficiency (Sugimoto et al. 2016). Sarcolemmal sphingomyelin was recently reported to be negatively related to insulin sensitivity in human muscle (Perreault et al. 2018). The evidence towards a role of the glycosphingolipid species in IR is somewhat more substantive. Pharmacological inhibition of glucosylceramide synthase, which catalyses the initial step in glycosphingolipid synthesis, has likewise demonstrably improved insulin sensitivity and glucose tolerance in $o b / o b$ mice, diet-induced obese mice and Zucker diabetic fatty rats (Aerts et al. 2007, Zhao et al. 2007). The ganglioside GM3 (ganglioside monosialo 3), which comprises a further derivation of glucosylceramide, has moreover been shown to mediate the effects of TNF $\alpha$ and directly interfere with the activity and membrane localisation of the insulin receptor to inhibit insulin signalling (Tagami et al. 2002, Yamashita et al. 2003, Kabayama et al. 2005, Kabayama et al. 2007). In providing the precursor to these detrimental sphingolipid species, ceramide synthesis, if perhaps not accumulation per se, can be attributed to a role in IR development.

\section{Discrepancies in the field of lipid-induced IR}

Despite the substantial literature linking aberrant accumulation of the aforementioned lipid classes with IR, there are many controversies in the field and the relative influence of any one of these lipids over another remains uncertain. The published literature is rife with studies which, when compared alongside each other, show discrepancies if not outright contradictions - with these opposing viewpoints particularly evident in DAGand ceramide-centric research. Studies demonstrating enhanced insulin action due to decreased DAG content are countered by those which show increased DAG levels without detriment to insulin sensitivity (Chavez et al. 2003, Brown et al. 2010, Amati et al. 2011, Turpin et al. 2011, Selathurai et al. 2015). Human studies correlating ceramide accumulation with IR are similarly contradicted by studies which report dissociation between the two (Itani et al.2002, Skovbro et al. 2008, Nowotny et al. 2013, Szendroedi et al. 2014), while inhibition of ceramide synthesis cannot always rescue insulin sensitivity (Lee et al. 2010). Another key example which demonstrates that elevated intracellular lipid may not always be an obligate inducer of IR is the so-called 'Athlete's Paradox'. Highly trained individuals have exquisite insulin sensitivity, despite elevated levels of multiple lipid classes including DAGs and ceramides (Goodpaster et al. 2001, Amati et al. 2011). The corresponding enhancement in the capacity for mitochondrial lipid oxidation in athletes is thought to largely underlie this phenomenon.

So why are discrepancies in this field so common? Some may be simply due to comparisons across markedly differing experimental setups and conditions, with experimental diets, housing temperatures, mouse strain and methodology for assessing insulin action (e.g. hyperinsulinemic-euglycemic clamps vs glucose tolerance tests or Akt phosphorylation) varying significantly between studies. Even the same transgenic mouse model of liver-specific DGAT2 (diacylglycerol O-acyltransferase 2) overexpression, in the hands of two different groups, produced disparate fold-changes in accumulated DAG and TAG, and entirely opposite conclusions: IR did not develop in the initial study (Monetti et al. 2007) but did in the second (Jornayvaz et al. 2011). Correlational studies could also potentially be misleading with regard to causation, much less sufficiency or necessity.

Interplay between lipid-related mechanisms is likely, and indeed at least nominally agreed upon (Meikle \& Summers 2017, Petersen \& Shulman 2017), as is the existence of as-yet-unidentified, non-canonical means of inducing IR. It is now becoming more broadly accepted, however, that seemingly contradictory evidence linking certain lipid species to IR is also perhaps a reflection of lipid subcellular location, the specific subspecies present and the timing of measurements relative to lipid fluxes.

\section{Subcellular localisation}

Lipids are not static within cells and most are typically not restricted to a specific subcellular location. Because signalling events and metabolism of nutrients are generally restricted to discrete locations within cells, it 
stands to reason that analysis of the 'bulk' lipids from an entire cell or tissue sample could obscure localised changes in key lipid species that are directly relevant to the process in question. But even though this concept is important and starting to gain traction, there is little consensus on the specific nature of these relationships. With respect to DAGs, several studies have associated IR development in muscle and liver with membrane DAG accumulation, reasoning that DAG activation of PKC at the membrane would have a major impact on the insulin signalling events that occur in this region (Bergman et al. 2012, Cantley et al. 2013, Chan et al. 2015). These studies suggest protective effects of DAG redistribution to lipid droplets and/or the lipid-associated ER (Bergman et al. 2012, Cantley et al. 2013, Chan et al. 2015). Despite this, others have found the precise reverse: that the key predictor of hepatic IR is cytosolic DAG accumulation, with membrane content only weakly related (Jornayvaz et al. 2011, Kumashiro et al. 2011, Ter Horst et al. 2017). Contradictory findings are largely unreconciled, and broadly attributed to experimental model or sample procurement and fractionation procedures (Bergman et al. 2012, Cantley et al. 2013). Moreover, recent work in human skeletal muscle indicates that potential relationships between subcellular distribution of DAG and insulin action might be more related to accumulation of specific DAG species at different intracellular sites, rather than the bulk content of DAG (Perreault et al. 2018).

The compartmentalisation of ceramide synthesis, just as for DAGs, produces localised lipid pools that are differentiated in composition and function. Ceramides are primarily generated de novo in the ER, but also from the hydrolysis of sphingomyelin at the plasma membrane and via sphingosine salvage in the mitochondria. Subcellular transport mechanisms, particularly to the Golgi where ceramides are further metabolised, show preferential targeting for specific ceramide species (Kumagai et al. 2005, Konstantynowicz-Nowicka et al. 2015, Kakazu et al. 2016, Yamaji et al. 2016), indicating the likelihood of differential function according to spatial distribution. Temporal studies have further found that ceramide species in the nucleus are differentially composed and regulated to those found in mitochondria (Aviram et al. 2016). Although relatively few studies have investigated the effects of ceramide subcellular localisation in the specific context of IR, it has been shown that ceramide content in subsarcolemmal, but not intermyofibrillar, mitochondria is related to IR parameters in postprandial humans (Chung et al. 2017a,b). More recently, an inverse relationship has been found between insulin sensitivity and ceramides of the sarcolemmal, mitochondrial/ER, and nuclear compartments in human muscle, with only the cytosolic lipids being unrelated (Perreault et al. 2018).

\section{Subspecies and isoform/isomer}

As described earlier, there are thousands of different lipid species, which we are now gaining a better appreciation of due to advances in analytical techniques. Using DAGs as an example, the primary de novo pathway of DAG biosynthesis occurs during TAG production, with the esterification of FAs to a phosphoglycerol backbone at $s n-1$ and -2 , within the ER and Golgi. DAGs are also derived from the (reversible) hydrolysis of phospholipids at the plasma membrane, and of TAGs at cytosolic lipid droplets, generating $s n-1,2$ and $s n-1,3$ DAGs respectively. There is now an appreciation that the biological effects of different DAG species are related to both variations in acyl chain length and saturation, as well as isomeric differences (position of bonds on the glycerol backbone i.e. sn-1,2, sn-1,3, sn-2,3).

The influence of isomer, considered within the context provided by the established PKC-centric mechanism of DAG-mediated IR, can also perhaps suggest some clarification of the discrepancies seen regarding the relevance of DAG subcellular location. PKC activation is conventionally quantified by protein translocation from cytosol to membrane, although some lack of clarity remains regarding the relative importance of recruitment in the cytosol vs activation at the membrane (see above). Nevertheless, multiple early studies found that PKC activation is stereospecific and achieved only by $s n-1,2$ DAGs (Rando \& Young 1984, Boni \& Rando 1985, Leach et al. 1991, Wakelam 1998, Takai et al. 2012). The sn-1,3 DAGs found in lipid droplets have no effect on PKC, and indeed their accumulation in muscle has recently been shown in mice to have no negative effects on insulin signalling or glucose uptake (Serup et al. 2016, Lundsgaard et al. 2017). Likewise, differentiation in human muscle insulin sensitivity has been found to be unrelated to $s n-1,3$ or $s n-2,3$ DAGs (Perreault et al. 2018). The PKCrelevant membrane-associated $s n-1,2$ pool is derived from phospholipid hydrolysis and even more specifically from PIP $_{2}$ (Leach et al. 1991). It is perhaps feasible that sn-1,2 DAG content can be relevant to PKC activation even when found in the cytosolic fraction, given that DAGs can be shuttled between the PM and ER (Saheki et al. 2016). A recent study in human muscle identified a positive relationship between insulin sensitivity and total $s n-1,2$ DAGs of the mitochondrial/ER and nuclear 
fractions, but within the mitochondrial/ER fraction, an inverse correlation was noted for disaturated $s n-1,2$ DAGs (Perreault et al. 2018).

PKC substrate preferences are further delimited by the length and degree of (un)saturation of DAG acyl chains, with the different isozymes displaying a variety of sensitivities. The IR-associated novel PKCs $\delta, \theta$ and $\varepsilon$ are for example preferentially activated by DAG species containing longer and polyunsaturated acyl chains (Marignani et al. 1996, Madani et al. 2001, Kamiya et al. 2016). Although measures of specific DAG acyl species are neither unanimously reported nor uniformly associated across the literature, the relationship has been at least partially corroborated on a whole-body scale (Holloway et al. 2014). Rodent studies taking a more interventionist approach have altered cellular DAG pool composition and abundance by, for example, targeting specific degradation or metabolism pathways, which also often possess specific preferences for DAG substrate species. Diacylglycerol kinases (DGKs) catalyse the conversion of DAGs to phosphatidic acid. The intracellular type II isoform DGK $\delta$ targets palmitic acidcontaining DAGs and its decreased expression is closely related to the development of IR (Chibalin et al. 2008, Sakai et al. 2014). In contrast, the ER- and plasma membranebound type III isoform DGKe, which is instrumental in PI-cycling, has particularly high specificity for PKCrelevant 18:0/20:4 DAG (Lung et al. 2009, Shulga et al. 2011, Nakano et al. 2016). Its ablation, despite increasing DAG levels, demonstrably increases whole-body glucose tolerance by means other than improving muscle insulin sensitivity (Mannerås-Holm et al. 2017).

As a determinant in dissecting conflicting results, however, DAG acyl species may not wholly apply in isolation: di-C18:0 DAG accumulation in muscle has been identified as the greatest contributor to DAGmediated IR (Van Hees et al. 2011, Bergman et al. 2012, Holloway et al. 2014), but also as preferentially correlated with the enhanced insulin sensitivity displayed by athletes (Amati et al. 2011) and, more recently, via calcitriol supplementation (Jefferson et al. 2017). There is some indication that chain length, too, can depend on subcellular location for its relevance. Ter Horst et al. (2017) have found accumulated cytosolic DAGs of C18:1C16:0, C16:0-C16:0 and C18:1-C18:1 to coincide with hepatic suppression of endogenous glucose production; membrane DAG of C20:4-C20:5 was meanwhile positively correlated with insulin sensitivity.

In contrast to the dual effect of acyl chain length and position on DAG function, the primary structural determinant differentiating ceramide subspecies and function is acyl chain length. Acylation is catalysed by the six ceramide synthase isoforms (CerS1-6), which are essential to two of the three ceramide synthesis pathways and display isoform-specific preferences for FA-CoA chain length (Tidhar et al. 2012, Tidhar \& Futerman 2013). Variable acylation grants ceramides correspondingly differentiated biophysical properties, and consequently differential interactions. These in some cases fulfil entirely opposing functions: C16-ceramide promotes cell apoptosis, whereas C24-ceramide is anti-apoptotic and promotes proliferation (Karahatay et al. 2007, Mesicek et al. 2010, Hartmann et al. 2012, Stiban \& Perera 2015). In the context of IR, long-chain (LC) and VLC ceramides have similarly divergent roles. C16-ceramide is identified as the critical species mediating impairment of glucose tolerance and hepatic insulin sensitivity (Raichur et al. 2014, Turpin et al. 2014). Mice deficient in this species were described to exhibit a favourable metabolic profile without significant pathologies (Turpin et al. 2014, Gosejacob et al. 2016). C18-ceramides, predominant in muscle and strongly correlated with whole-body glucose metabolism, are implicated as mediators of muscle IR and offer an additional target for beneficial reductions (Bergman et al. 2016, Blachnio-Zabielska et al. 2016, Tonks et al. 2016, Perreault et al. 2018).

The VLC ceramides (C>22), in contrast, are observed to promote favourable metabolic processes. With respect to insulin action, recent work has shown correlations between murine glucose homeostasis and C24-ceramide content in liver and that directly increasing C24-ceramide content improves insulin signalling (Montgomery et al. 2016). These findings are consistent with the glucose intolerance/IR observed in livers of CerS2-knockout mice and obese HFD-fed CerS2 haploinsufficient mice (Park et al. 2013, Raichur et al. 2014). In addition, elevations in C24-ceramide content have recently been associated with increased insulin sensitivity in skeletal and in cardiac muscle, both in vitro and in vivo (Xie et al. 2015, Chung et al. 2017b, Jefferson et al. 2017). Role differentiation mandates that, rather than total accumulation or deficit per se, cell health is underlain by ceramide equilibrium.

Shifts in ceramide acyl chain profile may occur naturally as an adaptive chronic cellular response to FA excess. Certainly, an apparent compensatory mechanism has been evident in human and murine models, in vitro and in vivo, adjusting ceramide ratio to maintain steady total levels following CerS deficiency (PewznerJung et al. 2010, Mullen et al. 2011). The identified range of epigenetic, transcriptional, post-transcriptional and post-translational CerS regulatory mechanisms moreover 
appear to be isoform specific (Wegner et al. 2016). Interaction with ELOVL1 (elongation of VLC FAs protein 1) or ACBP (acyl-CoA-binding protein), for example, stimulates specifically CerS2 and CerS3 (Sassa et al. 2013, Ferreira et al. 2017). Less is known, however, regarding regulatory impairment.

The effect of fatty acyl side chains extends beyond DAGs and ceramides, with specific acyl species of phospholipids, acylcarnitines and LCA-CoAs also implicated in IR (Borkman et al. 1993, Mihalik et al. 2010, Montgomery et al. 2017, Stöckli et al. 2017). As a final note, there may also be some further relevance to be found in acyl chain lengths when their associations with IR are compared across lipid species. The aforementioned divergence between LC- and VLC-Cer acyl species with regard to IR has recently been paralleled in a study relating LC-DAGs to IR and VLC-DAGs to insulin sensitivity (Ter Horst et al. 2017). Skeletal muscle IR has been associated with changes in C18-acyl chain species for both DAGs and ceramides alike (Bergman et al. 2012, Holloway et al. 2014, Szendroedi et al. 2014, Zabielski et al. 2017, Bergman et al. 2018, Perreault et al. 2018).

\section{Lipid fluxes - timing is everything}

Progression of IR is overtly and inherently time dependent. Any associated alterations in lipid content, whether stimulus or consequence, likewise develop over time, as has been clearly demonstrated on the whole-body scale (Kraegen et al. 1991, Turner et al. 2013). Both in vitro and in vivo studies have shown that the consequences of lipid oversupply are not only time dependent, but in some cases, also transient (Yu et al. 2002, Szendroedi et al. 2014, Roomp et al. 2017). Such transient shifts could well be missed if measurements are taken outside what can comprise a relatively narrow window: glucose-stimulated DAG turnover in $ß$-cells, for example, produces effects that are typically $<10$ s in duration (Wuttke et al. 2013). Even changes with genuine (patho)physiological relevance could also be masked by the inherent dynamism of natural cellular lipid metabolism. Flux rates through the elaborately interconnected metabolic pathways, within cells and between tissues, can appear disconnected from simple metabolite quantification and expression profiles (Turner et al. 2007, You et al. 2014, Harding et al. 2015). Futile cycles, converting substrate back and forth between reversible reactions, exacerbate the disconnection.

Conventionally, however, lipid analyses are with reference to the single time point at which the sample was taken and thus lose any contextual data on natural flux dynamics. Chosen time points may not accurately reflect transient responses in lipid metabolism and are frequently distinct from the timepoint where measures of insulin action/glucose homeostasis are taken (e.g. a glucose or insulin tolerance test are performed several days prior to the collection of tissue for biochemical analyses). While experimental design often dictates this requirement, the disconnect in timeframe may create ostensible but misleading correlations. The analysis of lipid flux, subspecies and subcellular compartmentationhowsoever beneficial to understanding-is also simply not always feasible to perform in combination.

\section{Perspective}

There is a large body of evidence linking disordered lipid metabolism with IR; yet, there is still significant controversy regarding the principal lipid(s) that impair insulin action. Advances in lipidomic techniques have revealed a new layer of complexity and other relevant techniques in this area are being developed (and adopted). Stable isotope studies permit labelled compounds to be tracked through metabolic pathways in either in vivo or in vitro setups (Magkos \& Mittendorfer 2009, Umpleby 2015). Recent investigation into lipid droplets has developed methodology for more accurate measurements of (instantaneous alterations in) lipogenic activity in living cells via time-course label-free stimulated Raman scattering (SRS) imaging (Zhang et al. 2017). Current advances in mass spectrometry have been more comprehensively reviewed elsewhere (Gross 2017, Triebl et al. 2017), but in brief, they offer increasingly sensitive lipid profiling techniques to better examine discrete spatial compartmentation and complex biological mixtures (Gethings et al. 2017, Gulin et al. 2017, Kaya et al. 2017, Xiang et al. 2017). Although hardly yet standard practice, these exciting new methodologies will increase our capacity to understand the finer details of lipid intermediate accumulation in IR and potentially reveal targets with therapeutic utility for treating obesity and type 2 diabetes.

\section{Declaration of interest}

The authors declare that there is no conflict of interest that could be perceived as prejudicing the impartiality of this review.

\section{Funding}

Research in the lab of the authors is supported by funding from the National Health and Medical Research Council of Australia and the Diabetes Australia Research Program. LKM is supported by an Australian Research Training Program Scholarship. 


\section{References}

Adams JM, Pratipanawatr T, Berria R, Wang E, DeFronzo RA, Sullards MC \& Mandarino LJ 2004 Ceramide content is increased in skeletal muscle from obese insulin-resistant humans. Diabetes $\mathbf{5 3} 25-31$. (https://doi.org/10.2337/diabetes.53.1.25)

Aerts JM, Ottenhoff R, Powlson AS, Grefhorst A, van Eijk M, Dubbelhuis PF, Aten J, Kuipers F, Serlie MJ, Wennekes T, et al. 2007 Pharmacological inhibition of glucosylceramide synthase enhances insulin sensitivity. Diabetes 56 1341-1349. (https://doi.org/10.2337/db06-1619)

Aguer C, Fiehn O, Seifert EL, Bézaire V, Meissen JK, Daniels A, Scott K, Renaud JM, Padilla M, Bickel DR, et al. 2013 Muscle uncoupling protein 3 overexpression mimics endurance training and reduces circulating biomarkers of incomplete $\beta$-oxidation. FASEB Journal $\mathbf{2 7}$ 4213-4225. (https://doi.org/10.1096/fj.13-234302)

Aguer C, McCoin CS, Knotts TA, Thrush AB, Ono-Moore K, McPherson R, Dent R, Hwang DH, Adams SH \& Harper M-E 2015 Acylcarnitines: potential implications for skeletal muscle insulin resistance. FASEB Journal 29 336-345. (https://doi.org/10.1096/fj.14-255901)

Amaro A, Fabbrini E, Kars M, Yue P, Schechtman K, Schonfeld G \& Klein S 2010 Dissociation between intrahepatic triglyceride content and insulin resistance in familial hypobetalipoproteinemia. Gastroenterology 139 149-153. (https://doi.org/10.1053/j.gastro.2010.03.039)

Amati F, Dubé JJ, Alvarez-Carnero E, Edreira MM, Chomentowski P, Coen PM Switzer GE, Bickel PE, Stefanovic-Racic M, Toledo FG, et al. 2011 Skeletal muscle triglycerides, diacylglycerols, and ceramides in insulin resistance: another paradox in endurance-trained athletes? Diabetes 60 2588-2597. (https://doi.org/10.2337/db10-1221)

Aviram R, Manella G, Kopelman N, Neufeld-Cohen A, Zwighaft Z, Elimelech M, Adamovich Y, Golik M, Wang C, Han X, et al. 2016 Lipidomics analyses reveal temporal and spatial lipid organisation and uncover daily oscillations in intracellular organelles. Molecular Cell 62 636-648. (https://doi.org/10.1016/j.molcel.2016.04.002)

Bellini L, Campana M, Mahfouz R, Carlier A, Véret J, Magnan C, Hajduch E \& Le Stunff H 2015 Targeting sphingolipid metabolism in the treatment of obesity/type 2 diabetes. Expert Opinion on Therapeutic Targets 19 1037-1050. (https://doi.org/10.1517/14728222 .2015.1028359)

Bergman BC, Hunerdosse DM, Kerege A, Playdon MC \& Perreault L 2012 Localisation and composition of skeletal muscle diacylglycerol predicts insulin resistance in humans. Diabetologia 55 1140-1150. (https://doi.org/10.1007/s00125-011-2419-7)

Bergman BC, Brozinick JT, Strauss A, Bacon S, Kerege A, Bui HH, Sanders P, Siddall P, Kuo MS \& Perreault L 2015 Serum sphingolipids: relationships to insulin sensitivity and changes with exercise in humans. American Journal of Physiology: Endocrinology and Metabolism 309 E398-E408. (https://doi.org/10.1152/ajpendo.00134.2015)

Bergman BC, Brozinick JT, Strauss A, Bacon S, Kerege A, Bui HH, Sanders P, Siddall P, Wei T, Thomas MK, et al. 2016 Muscle sphingolipids during rest and exercise: a C18:0 signature for insulin resistance in humans. Diabetologia 59 785-798. (https://doi.org/10.1007/s00125-015-3850-y)

Bergman BC, Perreault L, Strauss A, Bacon SD, Kerege AA, Harrison K, Brozinick JT, Hunerdosse DM, Playdon MC, Holmes W, et al. 2018 Intramuscular triglyceride synthesis: importance in muscle lipid partitioning in humans. American Journal of Physiology: Endocrinology and Metabolism 314 E152-E164. (https://doi.org/10.1152/ ajpcell.00137.2017)

Billecke N, Bosma M, Rock W, Fleissner F, Best G, Schrauwen P, Kersten S, Bonn M, Hesselink MKC \& Parekh SH 2015 Perilipin 5 mediated lipid droplet remodelling revealed by coherent Raman imaging. Integrative Biology 7 467-476. (https://doi.org/10.1039/C4IB00271G)

Bishop WR \& Bell RM 1988 Functions of diacylglycerol in glycerolipid metabolism, signal transduction and cellular transformation. Oncogene Research 2 205-218.

Blachnio-Zabielska AU, Chacinska M, Vendelbo MH \& Zabielski P 2016 The crucial role of C18-Cer in fat-induced skeletal muscle insulin resistance. Cell Physiology and Biochemistry 40 1207-1220. (https:// doi.org/10.1159/000453174)

Boni LT \& Rando RR 1985 The nature of protein kinase C activation by physically defined phospholipid vesicles and diacylglycerols. Journal of Biological Chemistry 260 10819-10825.

Borkman M, Storlien LH, Pan DA, Jenkins AB, Chisholm DJ \& Campbell LV 1993 The relation between insulin sensitivity and the fatty-acid composition of skeletal-muscle phospholipids. New England Journal of Medicine 328 238-244. (https://doi.org/10.1056/ NEJM199301283280404)

Bosma M, Kersten S, Hesselink MK \& Schrauwen P 2012 Re-evaluating lipotoxic triggers in skeletal muscle: relating intramyocellular lipid metabolism to insulin sensitivity. Progress in Lipid Research 51 36-49. (https://doi.org/10.1016/j.plipres.2011.11.003)

Bourbon NA, Yun J \& Kester M 2000 Ceramide directly activates protein kinase $\mathrm{C} \zeta$ to regulate a stress-activated protein kinase signaling complex. Journal of Biological Chemistry 275 35617-35623. (https:// doi.org/10.1074/jbc.M007346200)

Bourbon NA, Sandirasegarane L \& Kester M 2002 Ceramide-induced inhibition of Akt is mediated through protein kinase Cร: implications for growth arrest. Journal of Biological Chemistry 277 3286-3292. (https://doi.org/10.1074/jbc.M110541200)

Brown JM, Betters JL, Lord C, Ma Y, Han X, Yang K, Alger HM, Melchior J, Sawyer J, Shah R, et al. 2010 CGI-58 knockdown in mice causes hepatic steatosis but prevents diet-induced obesity and glucose intolerance. Journal of Lipid Research 51 3306-3315. (https://doi. org/10.1194/jlr.M010256)

Campana M, Bellini L, Rouch C, Rachdi L, Coant N, Butin N, Bandet CL, Philippe E, Meneyrol K, Kassis N, et al. 2018 Inhibition of central de novo ceramide synthesis restores insulin signalling in hypothalamus and enhances $\beta$-cell function of obese Zucker rats. Molecular Metabolism 8 23-36. (https://doi.org/10.1016/j. molmet.2017.10.013)

Cantley JL, Yoshimura T, Camporez JPG, Zhang D, Jornayvaz FR, Kumashiro N, Guebre-Egziabher F, Jurczak MJ, Kahn M, Guigni BA, et al. 2013 CGI-58 knockdown sequesters diacylglycerols in lipid droplets/ER-preventing diacylglycerol-mediated hepatic insulin resistance. PNAS 110 1869-1874. (https://doi.org/10.1073/ pnas.1219456110)

Capel F, Cheraiti N, Acquaviva C, Hénique C, Bertrand-Michel J, VianeySaban C, Prip-Buus C \& Morio B 2016 Oleate dose-dependently regulates palmitate metabolism and insulin signalling in $\mathrm{C} 2 \mathrm{C} 12$ myotubes. Biochimica et Biophysica Acta 1861 2000-2010. (https:// doi.org/10.1016/j.bbalip.2016.10.002)

Chan SMH, Zeng XY, Sun RQ, Jo E, Zhou X, Wang H, Li S, Xu A, Watt MJ \& Ye JM 2015 Fenofibrate insulates diacylglycerol in lipid droplet/ER and preserves insulin signalling transduction in the liver of high fat fed mice. Biochimica et Biophysica Acta 1852 1511-1519. (https://doi.org/10.1016/j.bbadis.2015.04.005)

Chavez JA \& Summers SA 2003 Characterising the effects of saturated fatty acids on insulin signalling and ceramide and diacylglycerol accumulation in 3T3-L1 adipocytes and C2C12 myotubes. Archives of Biochemistry and Biophysics 419 101-109. (https://doi.org/10.1016/j. abb.2003.08.020)

Chavez JA \& Summers SA 2012 A ceramide-centric view of insulin resistance. Cell Metabolism 15 585-594. (https://doi.org/10.1016/j. cmet.2012.04.002)

Chavez JA, Knotts TA, Wang LP, Li G, Dobrowsky RT, Florant GL \& Summers SA 2003 A role for ceramide, but not diacylglycerol, in the antagonism of insulin signal transduction by saturated fatty acids. Journal of Biological Chemistry 278 10297-10303. (https://doi. org/10.1074/jbc.M212307200)

Chen TC, Benjamin DI, Kuo T, Lee RA, Li ML, Mar DJ, Costello DE, Nomura DK \& Wang JC 2017 The glucocorticoid-Angptl4-ceramide axis induces insulin resistance through PP2A and PKCל. Science Signaling 10 eaaai7905. (https://doi.org/10.1126/scisignal.aai7905) 
Chibalin AV, Leng Y, Vieira E, Krook A, Bjornholm M, Long YC, Kotova O, Zhong Z, Sakane F, Steiler T, et al. 2008 Downregulation of diacylglycerol kinase delta contributes to hyperglycemia-induced insulin resistance. Cell 132 375-386. (https://doi.org/10.1016/j. cell.2007.12.035)

Chitraju C, Mejhert N, Haas JT, Diaz-Ramirez LG, Grueter CA, Imbriglio JE, Pinto S, Koliwad SK, Walther TC \& Farese Jr RV 2017 Triglyceride synthesis by DGAT1 protects adipocytes from lipidinduced ER stress during lipolysis. Cell Metabolism 26 407-418. (https://doi.org/10.1016/j.cmet.2017.07.012)

Choi CS, Savage DB, Abu-Elheiga L, Liu ZX, Kim S, Kulkarni A, Distefano A, Hwang YJ, Reznick RM, Codella R, et al. 2007 Continuous fat oxidation in acetyl-CoA carboxylase 2 knockout mice increases total energy expenditure, reduces fat mass, and improves insulin sensitivity. PNAS 104 16480-16485. (https://doi.org/10.1073/pnas.0706794104)

Chung JO, Koutsari C, Blachnio-Zabielska AU, Hames KC \& Jensen MD $2017 a$ Intramyocellular ceramides: subcellular concentrations and fractional de novo synthesis in postabsorptive humans. Diabetes 66 2082-2091. (https://doi.org/10.2337/db17-0082)

Chung JO, Koutsari C, Blachnio-Zabielska AU, Hames KC \& Jensen MD $2017 b$ Effects of meal ingestion on intramyocellular ceramide concentrations and fractional de novo synthesis in humans. American Journal of Physiology: Endocrinology and Metabolism 314 E105-E114. (https://doi.org/10.1152/ajpendo.00153.2017)

Clore JN, Harris PA, Li J, Azzam A, Gill R, Zuelzer W, Rizzo WB \& Blackard WG 2000 Changes in phosphatidylcholine fatty acid composition are associated with altered skeletal muscle insulin responsiveness in normal man. Metabolism 49 232-238. (https://doi. org/10.1016/S0026-0495(00)91455-0)

Cnop M, Hannaert JC, Hoorens A, Eizirik DL \& Pipeleers DG 2001 Inverse relationship between cytotoxicity of free fatty acids in pancreatic islet cells and cellular triglyceride accumulation. Diabetes 50 1771-1777. (https://doi.org/10.2337/diabetes.50.8.1771)

Coen PM, Dubé JJ, Amati F, Stefanovic-Racic M, Ferrell RE, Toledo FG \& Goodpaster BH 2010 Insulin resistance is associated with higher intramyocellular triglycerides in type I but not type II myocytes concomitant with higher ceramide content. Diabetes 59 80-88. (https://doi.org/10.2337/db09-0988)

Coll T, Eyre E, Rodríguez-Calvo R, Palomer X, Sánchez RM, Merlos M, Laguna JC \& Vázquez-Carrera M 2008 Oleate reverses palmitateinduced insulin resistance and inflammation in skeletal muscle cells. Journal of Biological Chemistry 283 11107-11116. (https://doi. $\operatorname{org} / 10.1074 /$ jbc.M708700200)

Corkey BE, Deeney JT, Yaney GC, Tornheim K \& Prentki M 2000 The role of long-chain fatty acyl-CoA esters in beta-cell signal transduction. Journal of Nutrition 130 299S-304S. (https://doi. org/10.1093/jn/130.2.299S)

Dekker MJ, Baker C, Naples M, Samsoondar J, Zhang R, Qiu W, Sacco J \& Adeli K 2013 Inhibition of sphingolipid synthesis improves dyslipidemia in the diet-induced hamster model of insulin resistance: evidence for the role of sphingosine and sphinganine in hepatic VLDL-apoB100 overproduction. Atherosclerosis 228 98-109. (https://doi.org/10.1016/j.atherosclerosis.2013.01.041)

De Souza CJ, Eckhardt M, Gagen K, Dong M, Chen W, Laurent D \& Burkey BF 2001 Effects of poglitazone on adipose tissue remodelling within the setting of obesity and insulin resistance. Diabetes $\mathbf{5 0}$ 1863-1871. (https://doi.org/10.2337/diabetes.50.8.1863)

Deurenberg P, Weststrate JA \& Seidell JC 1991 Body mass index as a measure of body fatness: age- and sex-specific prediction formulas. British Journal of Nutrition 65 105-114. (https://doi.org/10.1079/ BJN19910073)

Dey R, Majumder N, Bhattacharjee S, Majumdar SB, Banerjee R, Ganguly S, Das P \& Majumdar S 2007 Leishmania donovani-induced ceramide as the key mediator of Akt dephosphorylation in murine macrophages: roles of protein kinase $\mathrm{C}_{\zeta}$ and phosphatase. Infection and Immunity 75 2136-2142. (https://doi.org/10.1128/IAI.01589-06)
Doege H, Grimm D, Falcon A, Tsang B, Storm TA, Xu H, Ortegon AM, Kazantzis M, Kay MA \& Stahl A 2008 Silencing of hepatic fatty acid transporter protein 5 in vivo reverses diet-induced non-alcoholic fatty liver disease and improves hyperglycemia. Journal of Biological Chemistry 283 22186-22192. (https://doi.org/10.1074/jbc. M803510200)

Donath MY \& Shoelson SE 2011 Type 2 diabetes as an inflammatory disease. Nature Reviews Immunology 11 98-107. (https://doi. org/10.1038/nri2925)

Dubé JJ, Amati F, Stefanovic-Racic M, Toledo FG, Sauers SE \& Goodpaster BH 2008 Exercise-induced alterations in intramyocellular lipids and insulin resistance: the athlete's paradox revisited. American Journal of Physiology: Endocrinology and Metabolism 294 E882-E888. (https://doi.org/10.1152/ajpendo.00769.2007)

Dubé JJ, Amati F, Toledo FG, Stefanovic-Racic M, Rossi A, Coen P \& Goodpaster BH 2011 Effects of weight loss and exercise on insulin resistance, and intramyocellular triacylglycerol, diacylglycerol and ceramide. Diabetologia 54 1147-1156. (https://doi.org/10.1007/ s00125-011-2065-0)

Eliasson B, Smith U, Mullen S, Cushman SW, Sherman AS \& Yang J 2014 Amelioration of insulin resistance by rosiglitazone is associated with increased adipose cell size in obese type 2 diabetic patients. Adipocyte 3 314-321. (https://doi.org/10.4161/adip.34425)

Ellis BA, Poynten A, Lowy AJ, Furler SM, Chisholm DJ, Kraegen EW \& Cooney GJ 2000 Long-chain acyl-CoA esters as indicators of lipid metabolism and insulin sensitivity in rat and human muscle. American Journal of Physiology: Endocrinology and Metabolism 279 E554-E560. (https://10.1152/ajpendo.2000.279.3.E554)

Erion DM \& Shulman GI 2010 Diacylglycerol-mediated insulin resistance. Nature Medicine 16 400-402. (https://doi.org/10.1038/ nm0410-400)

Færgeman NJ \& Knudsen J 1997 Role of long-chain fatty acyl-CoA esters in the regulation of metabolism and in cell signalling. Biochemical Journal 323 1-12.

Falcon A, Doege H, Fluitt A, Tsang B, Watson N, Kay MA \& Stahl A 2010 FATP2 is a hepatic fatty acid transporter and peroxisomal very longchain acyl-CoA synthetase. American Journal of Physiology: Endocrinology and Metabolism 299 E384-E393. (https://doi. org/10.1152/ajpendo.00226.2010)

Fasching P, Ratheiser K, Waldhäusl W, Rohac M, Osterrode W, Nowotny P \& Vierhapper H 1991 Metabolic effects of fish-oil supplementation in patients with impaired glucose tolerance. Diabetes 40 583-589. (https://doi.org/10.2337/diab.40.5.583)

Ferreira NS, Engelsby H, Neess D, Kelly SL, Volpert G, Merrill AH, Futerman AH \& Færgeman NJ 2017 Regulation of very-long acyl chain ceramide synthesis by acyl-CoA-binding protein. Journal of Biological Chemistry 292 7588-7597. (https://doi.org/10.1074/jbc. M117.785345)

Fex M \& Mulder H 2008 Lipases in the pancreatic beta-cell: implications for insulin secretion. Biochemical Society Transactions 36 885-890. (https://doi.org/10.1042/BST0360885)

Fox TE, Houck KL, O’Neill SM, Nagarajan M, Stover TC, Pomianowski PT, Unal O, Yun JK, Naides SJ \& Kester M 2007 Ceramide recruits and activates protein kinase $\mathrm{C} \zeta(\mathrm{PKC} \zeta)$ within structured membrane microdomains. Journal of Biological Chemistry 282 12450-12457. (https://doi.org/10.1074/jbc.M700082200)

Frangioudakis G, Garrard J, Raddatz K, Nadler JL, Mitchell TW \& Schmitz-Peiffer C 2010 Saturated- and n-6 polyunsaturated-fat diets each induce ceramide accumulation in mouse skeletal muscle: reversal and improvement of glucose tolerance by lipid metabolism inhibitors. Endocrinology 151 4187-4196. (https://doi.org/10.1210/ en.2010-0250)

Funai K, Song H, Yin L, Lodhi IJ, Wei X, Yoshino J, Coleman T \& Semenkovich CF 2013 Muscle lipogenesis balances insulin sensitivity and strength through calcium signalling. Journal of Clinical Investigation 123 1229-1240. (https://doi.org/10.1172/JCI65726) 
Funai K, Lodhi IJ, Spears LD, Yin L, Song H, Klein S \& Semenkovich CF 2016 Skeletal muscle phospholipid metabolism regulates insulin sensitivity and contractile function. Diabetes 65 358-370. (https:// doi.org/10.2337/db15-0659)

Gao X, Lowry PR, Zhou X, Depry C, Wei Z, Wong GW \& Zhang J 2011 PI3K/Akt signalling requires spatial compartmentalisation in plasma membrane microdomains. PNAS 108 14509-14514. (https://doi. org/10.1073/pnas.1019386108)

Garbacz WG, Lu P, Miller TM, Poloyac SM, Eyre NS, Mayrhofer G, Xu M, Ren S \& Xie W 2016 Hepatic overexpression of CD36 improves glycogen homeostasis and attenuates high-fat diet-induced hepatic steatosis and insulin resistance. Molecular and Cell Biology $\mathbf{3 6}$ 2715-2727. (https://doi.org/10.1128/MCB.00138-16)

Gemmink A, Bosma M, Kuijpers HJH, Hoeks J, Schaart G, van Zandvoort MAMJ, Schrauwen P \& Hesselink MKC 2016 Decoration of intramyocellular lipid droplets with PLIN5 modulates fastinginduced insulin resistance and lipotoxicity in humans. Diabetologia 59 1040-1048. (https://doi.org/10.1007/s00125-016-3865-z)

Gethings LA, Richardson K, Wildgoose J, Lennon S, Jarvis S, Bevan CL, Vissers JPC \& Langridge JI 2017 Lipid profiling of complex biological mixtures by liquid chromatography/mass spectrometry using a novel scanning quadrupole data-independent acquisition strategy. Rapid Communications in Mass Spectrometry 31 1599-1606. (https://doi. org $/ 10.1002 / \mathrm{rcm} .7941)$

González-Périz A, Horrillo R, Ferré N, Gronert K, Dong B, MoránSalvador E, Titos E, Martínez-Clemente M, López-Parra M, Arroyo V, et al. 2009 Obesity-induced insulin resistance and hepatic steatosis are alleviated by $\omega-3$ fatty acids: a role for resolvins and protectins. FASEB Journal 23 1946-1957. (https://doi.org/10.1096/fj.08-125674)

Goodpaster BH, He J, Watkins S \& Kelley DE 2001 Skeletal muscle lipid content and insulin resistance: evidence for a paradox in endurancetrained athletes. Journal of Clinical Endocrinology and Metabolism $\mathbf{8 6}$ 5755-5761. (https://doi.org/10.1210/jcem.86.12.8075)

Gorgani-Firuzjaee S, Ahmadi S \& Meshkani R 2014 Palmitate induces SHIP2 expression via the ceramide-mediated activation of NF- $\mathrm{kB}$, and JNK in skeletal muscle cells. Biochemical and Biophysical Research Communications 450 494-499. (https://doi.org/10.1016/j. bbrc.2014.06.006)

Gosejacob D, Jäger PS, Vom Dorp K, Frejno M, Carstensen AC, Köhnke M, Degen J, Dörmann P \& Hoch M 2016 Ceramide synthase 5 is essential to maintain C16:0-ceramide pools and contributes to the development of diet-induced obesity. Journal of Biological Chemistry 291 6989-7003. (https://doi.org/10.1074/jbc.M115.691212)

Gregor MF \& Hotamisligil GS 2011 Inflammatory mechanisms in obesity Annual Review of Immunology 29 415-445. (https://doi.org/10.1146/ annurev-immunol-031210-101322)

Gross RW 2017 The evolution of lipidomics through space and time. Biochimica et Biophysica Acta 1862 731-739. (https://doi. org/10.1016/j.bbalip.2017.04.006)

Gual P, Le Marchand-Brustel Y \& Tanti JF 2005 Positive and negative regulation of insulin signalling through IRS-1 phosphorylation. Biochimie 87 99-109. (https://doi.org/10.1016/j.biochi.2004.10.019)

Gulin AA, Pavlyukov MS, Gusev SA, Malakhova YN, Buzin AI, Chvalun SN, Aldarov KG, Klinov DV, Gularyan SK \& Nadtochenko VA 2017 Applicability of TOF-SIMS for the assessment of lipid composition of cell membrane structures. Biochemistry $\mathbf{1 1}$ 144-150. (https://doi.org/10.1134/S1990747817020052)

Hage Hassan R, Pacheco de Sousa AC, Mahfouz R, Hainault I, BlachnioZabielska A, Bourron O, Koskas F, Górski J, Ferré P, Foufelle F, et al. 2016 Sustained action of ceramide on the insulin signaling pathway in muscle cells: implication of the double-stranded rna-activated protein kinase. Journal of Biological Chemistry 291 3019-3029. (https://doi.org/10.1074/jbc.M115.686949)

Hancock CR, Han DH, Chen M, Terada S, Yasuda T, Wright DC \& Holloszy JO 2008 High-fat diets cause insulin resistance despite an increase in muscle mitochondria. PNAS 105 7815-7820. (https://doi. org/10.1073/pnas.0802057105)

(c) 2019 Society for Endocrinology Published by Bioscientifica Ltd. Printed in Great Britain
Hannun YA, Loomis CR \& Bell RM 1986 Protein kinase C activation in mixed micelles. Mechanistic implications of phospholipid, diacylglycerol, and calcium interdependencies. Journal of Biological Chemistry 261 7184-7190.

Harding SV, Bateman KP, Kennedy BP, Rideout TC \& Jones PJ 2015 Desaturation index versus isotopically measured de novo lipogenesis as an indicator of acute systemic lipogenesis. BMC Research Notes $\mathbf{8}$ 49. (https://doi.org/10.1186/s13104-015-1016-0)

Hartmann D, Lucks J, Fuchs S, Schiffmann S, Schreiber Y, Ferreirós N, Merkens J, Marschalek R, Geisslinger G \& Grösch S 2012 Long chain ceramides and very long chain ceramides have opposite effects on human breast and colon cancer cell growth. International Journal of Biochemistry and Cell Biology 44 620-628. (https://doi.org/10.1016/j. biocel.2011.12.019)

Haugaard SB, Madsbad S, Høy CE \& Vaag A 2006 Dietary intervention increases n-3 long-chain polyunsaturated fatty acids in skeletal muscle membrane phospholipids of obese subjects. Implications for insulin sensitivity. Clinical Endocrinology 64 169-178. (https://doi. org/10.1111/j.1365-2265.2006.02444.x)

Haus JM, Kashyap SR, Kasumov T, Zhang R, Kelly KR, DeFronzo RA \& Kirwan JP 2009 Plasma ceramides are elevated in obese subjects with type 2 diabetes and correlate with the severity of insulin resistance. Diabetes 58 337-343. (https://doi.org/10.2337/db08-1228)

Hehner SP, Hofmann TG, Ushmorov A, Dienz O, Leung IWL, Lassam N, Scheidereit C, Dröge W \& Schmitz ML 2000 Mixed-lineage kinase 3 delivers CD3/CD28-derived signals into the IкB kinase complex. Molecular and Cell Biology 20 2556-2568. (https://doi.org/10.1128/ МСВ.20.7.2556-2568.2000)

Henique C, Mansouri A, Fumey G, Lenoir V, Girard J, Bouillaud F, PripBuus C \& Cohen I 2010 Increased mitochondrial fatty acid oxidation is sufficient to protect skeletal muscle cells from palmitate-induced apoptosis. Journal of Biological Chemistry 285 36818-36827. (https:// doi.org/10.1074/jbc.M110.170431)

Héron-Milhavet L, Haluzik M, Yakar S, Gavrilova O, Pack S, Jou WC, Ibrahimi A, Kim H, Hunt D, Yau D, et al. 2004 Muscle-specific overexpression of CD36 reverses the insulin resistance and diabetes of MKR mice. Endocrinology 145 4667-4676. (https://doi.org/10.1210/ en.2003-1543)

Hertz R, Magenhelm J, Berman I \& Bar-Tana J 1998 Fatty acyl-CoA thioesters are ligands of hepatic nuclear factor- $4 \alpha$. Nature 392 512-516. (https://doi.org/10.1038/33185)

Hoeks J, de Wilde J, Hulshof MFM, van den Berg SAA, Schaart G, van Dijk KW, Smit E \& Mariman ECM 2011 High fat dietinduced changes in mouse muscle mitochondrial phospholipids do not impair mitochondrial respiration despite insulin resistance. PLoS ONE 6 e27274. (https://doi.org/10.1371/journal. pone.0027274)

Holland WL, Brozinick JT, Wang LP, Hawkins ED, Sargent KM, Liu Y, Narra K, Hoehn KL, Knotts TA, Siesky A, et al. 2007 Inhibition of ceramide synthesis ameliorates glucocorticoid-, saturated-fat-, and obesity-induced insulin resistance. Cell Metabolism 5 167-179. (https://doi.org/10.1016/j.cmet.2007.01.002)

Holland WL, Xia JY, Johnson JA, Sun K, Pearson MJ, Sharma AX, Quittner-Strom E, Tippetts TS, Gordillo R \& Scherer PE 2017 Inducible overexpression of adiponectin receptors highlight the roles of adiponectin-induced ceramidase signalling in lipid and glucose homeostasis. Molecular Metabolism 6 267-275. (https://doi. org/10.1016/j.molmet.2017.01.002)

Holloway GP, Chou CJ, Lally J, Stellingwerff T, Maher AC, Gavrilova O, Haluzik M, Alkhateeb H, Reitman ML \& Bonen A 2011 Increasing skeletal muscle fatty acid transport protein 1 (FATP1) targets fatty acids to oxidation and does not predispose mice to diet-induced insulin resistance. Diabetologia 54 1457. (https://doi.org/10.1007/ s00125-011-2114-8)

Holloway GP, Han XX, Jain SS, Bonen A \& Chabowski A 2014 Chronic muscle stimulation improves insulin sensitivity while increasing subcellular lipid droplets and reducing selected diacylglycerol and 
ceramide species in obese Zucker rats. Diabetologia 57 832-840. (https://doi.org/10.1007/s00125-014-3169-0)

Hoy AJ, Brandon AE, Turner N, Watt MJ, Bruce CR, Cooney GJ \& Kraegen EW 2009 Lipid and insulin infusion-induced skeletal muscle insulin resistance is likely due to metabolic feedback and not changes in IRS-1, Akt, or AS160 phosphorylation. American Journal of Physiology: Endocrinology and Metabolism 297 E67-E75. (https://doi. org/10.1152/ajpendo.90945.2008)

Humphrey SJ, Yang G, Yang P, Fazakerley DJ, Stöckli J, Yang JY \& James DE 2013 Dynamic adipocyte phosphoproteome reveals that Akt directly regulates mTORC2. Cell Metabolism 17 1009-1020. (https://doi.org/10.1016/j.cmet.2013.04.010)

Ibrahimi A, Bonen A, Blinn WD, Hajri T, Li X, Zhong K, Cameron R \& Abumrad NA 1999 Muscle-specific overexpression of FAT/CD36 enhances fatty acid oxidation by contracting muscle, reduces plasma triglycerides and fatty acids, and increase plasma glucose and insulin. Journal of Biological Chemistry 274 26761-26766. (https://doi. org/10.1074/jbc.274.38.26761)

Itani SI, Ruderman NB, Schmieder F \& Boden G 2002 Lipid-induced insulin resistance in human muscle is associated with changes in diacylglycerol, protein kinase C, and IkappaB-alpha. Diabetes 51 2005-2011. (https://doi.org/10.2337/diabetes.51.7.2005)

Janovská A, Hatzinikolas G, Mano M \& Wittert GA 2010 The effect of dietary fat content on phospholipid fatty acid profile is muscle fiber type dependent. American Journal of Physiology: Endocrinology and Metabolism 298 E779-E786. (https://doi.org/10.1152/ ajpendo.00356.2009)

Jefferson GE, Schnell DM, Thomas DT \& Bollinger LM 2017 Calcitriol concomitantly enhances insulin sensitivity and alters myocellular lipid partitioning in high fat-treated skeletal muscle cells. Journal of Physiology and Biochemistry 73 613-621. (https://doi.org/10.1007/ s13105-017-0595-8)

Johannsen DL, Tchoukalova Y, Tam CS, Covington JD, Xie W, Schwarz JM, Bajpeyi S \& Ravussin E 2014 Effect of 8 weeks of overfeeding on ectopic fat deposition and insulin sensitivity: testing the "adipose tissue expandability" hypothesis. Diabetes $\mathbf{3 7}$ 2789-2797. (https://doi.org/10.2337/dc14-0761)

Jornayvaz FR, Birkenfeld AL, Jurczak MJ, Kanda S, Guigni BA, Jiang DC, Zhang D, Lee HY, Samuel VT \& Shulman GI 2011 Hepatic insulin resistance in mice with hepatic overexpression of diacylglycerol acyltransferase 2. PNAS 108 5748-5752. (https://doi.org/10.1073/ pnas.1103451108)

Kabayama K, Sato T, Kitamura F, Uemura S, Kang BW, Igarashi Y \& Inokuchi J 2005 TNFalpha-induced insulin resistance in adipocytes as a membrane microdomain disorder: involvement of ganglioside GM3. Glycobiology 15 21-29. (https://doi.org/10.1093/glycob/cwh135)

Kabayama K, Sato T, Saito K, Loberto N, Prinetti A, Sonnino S, Kinjo M, Igarashi Y \& Inokuchi J 2007 Dissociation of the insulin receptor and caveolin-1 complex by ganglioside GM3 in the state of insulin resistance. PNAS 104 13678-13683. (https://doi.org/10.1073/ pnas.0703650104)

Kakazu E, Mauer AS, Yin M \& Malhi H 2016 Hepatocytes release ceramide-enriched pro-inflammatory extracellular vesicles in an IRE1 $\alpha$-dependent manner. Journal of Lipid Research 57 233-245. (https://doi.org/10.1194/jlr.M063412)

Kamiya Y, Mizuno S, Komenoi S, Sakai H \& Sakane F 2016 Activation of conventional and novel protein kinase $\mathrm{C}$ isozymes by different diacylglycerol molecular species. Biochemistry and Biophysics Reports 7 361-366. (https://doi.org/10.1016/j.bbrep.2016.07.017)

Karahatay S, Thomas K, Koybasi S, Senkal CE, Elojeimy S, Liu X, Bielawski J, Day TA, Gillespie MB, Sinha D, et al. 2007 Clinical relevance of ceramide metabolism in the pathogenesis of human head and neck squamous cell carcinoma (HNSCC): attenuation of C 18-ceramide in HNSCC tumors correlates with lymphovascular invasion and nodal metastasis. Cancer Letters 256 101-111. (https:// doi.org/10.1016/j.canlet.2007.06.003)
Kaya I, Brinet D, Michno W, Başkurt M, Zetterberg H, Blenow K \& Hanrieder J 2017 Novel trimodal MALDI imaging mass spectrometry (IMS3) at $10 \mu \mathrm{m}$ reveals spatial lipid and peptide correlates implicated in A $\beta$ plaque pathology in Alzheimer's Disease. ACS Chemical Neuroscience 8 2778-2790. (https://doi.org/10.1021/ acschemneuro.7b00314)

Kelley DE, He J, Menshikova EV \& Ritov VB 2002 Dysfunction of mitochondria in human skeletal muscle in type 2 diabetes. Diabetes 51 2944-2950. (https://doi.org/10.2337/diabetes.51.10.2944)

Kim JI, Huh JY, Sohn JH, Choe SS, Lee YS, Lim CY, Jo A, Park SB, Han W \& Kim JB 2015 Lipid-overloaded enlarged adipocytes provoke insulin resistance independent of inflammation. Molecular and Cellular Biology 35 1686-1699. (https://doi.org/10.1128/MCB.01321-14)

Kim JK, Fillmore JJ, Chen Y, Yu C, Moore IK, Pypaert M, Lutz EP, Kako Y, Velez-Carrasco W, Goldberg IJ, et al. 2001 Tissue-specific overexpression of lipoprotein lipase causes tissue-specific insulin resistance. PNAS 98 7522-7527. (https://doi.org/10.1073/pnas.121164498)

Kim JK, Gimeno RE, Higashimori T, Kim HJ, Choi H, Punreddy S, Mozell RL, Tan G, Stricker-Krongrad A, Hirsch DJ, et al. 2004a Inactivation of fatty acid transport protein 1 prevents fat-induced insulin resistance in skeletal muscle. Journal of Clinical Investigation 113 756-763. (https://doi.org/10.1172/JCI200418917)

Kim JK, Fillmore JJ, Sunshine MJ, Albrecht B, Higashimori T, Kim DW, Liu ZX, Soos TJ, Cline GW, O'Brien WR, et al. 2004b PKC- $\theta$ knockout mice are protected from fat-induced insulin resistance. Journal of Clinical Investigation 114 823-827. (https://doi.org/10.1172/ JCI200422230)

Kim KY, Kim BC, Xu Z \& Kim SJ 2004 Mixed lineage kinase 3 (MLK3)activated p38 MAP kinase mediates transforming growth factor-betainduced apoptosis in hepatoma cells. Journal of Biological Chemistry 279 29478-29484. (https://doi.org/10.1074/jbc.M313947200)

Kim OK, Jun W \& Lee J 2015 Mechanism of ER stress and inflammation for hepatic insulin resistance in obesity. Annals of Nutrition and Metabolism 67 218-27. (https://doi.org/10.1159/000440905)

Konstantynowicz-Nowicka K, Harasim E, Baranowski M \& Chabowski A 2015 New evidence for the role of ceramide in the development of hepatic insulin resistance. PLOS ONE 10 e0116858. (https://doi. org/10.1371/journal.pone.0116858)

Koves TR, Ussher JR, Noland RC, Slentz D, Mosedale M, Ilkayeva O, Bain J, Stevens R, Dyck JR, Newgard CB, et al. 2008 Mitochondrial overload and incomplete fatty acid oxidation contribute to skeletal muscle insulin resistance. Cell Metabolism 7 45-56. (https://doi. org/10.1016/j.cmet.2007.10.013)

Kraegen EW, Clark PW, Jenkins AB, Daley EA, Chisholm DJ \& Storlien LH 1991 Development of muscle insulin resistance after liver insulin resistance in high-fat-fed rats. Diabetes 40 1397-1403. (https://doi.org/10.2337/diab.40.11.1397)

Kumagai K, Yasuda S, Okemoto K, Nishijima M, Kobayashi S \& Hanada K 2005 CERT mediates intermembrane transfer of various molecule species of ceramides. Journal of Biological Chemistry 280 6488-6495. (https://doi.org/10.1074/jbc.M409290200)

Kumashiro N, Erion DM, Zhang D, Kahn M, Beddow SA, Chu X, Still CD, Gerhard GS, Han X, Dziura J, et al. 2011 Cellular mechanism of insulin resistance in non-alcoholic fatty liver disease. PNAS 108 16381-16385. (https://doi.org/10.1073/ pnas.1113359108)

Lasserre R, Guo XJ, Conchonaud F, Hamon Y, Hawchar O, Bernard AM, Soudja SM, Lenne PF, Rigneault H, Olive D, et al. 2008 Raft nanodomains contribute to Akt/PKB plasma membrane recruitment and activation. Nature Chemical Biology 4 538-547. (https://doi. org/10.1038/nchembio.103)

Leach KL, Ruff VA, Wright TM, Pessin MS \& Raben DM 1991 Dissociation of protein kinase $\mathrm{C}$ activation and sn-1,2-diacylglycerol formation. Comparison of phosphatidylinositol- and phosphatidylcholine-derived diglycerides in alpha-thrombinstimulated fibroblasts. Journal of Biological Chemistry 266 3215-3221. 
Lee J, Choi J, Selen Alpergin ES, Zhao L, Hartung T, Scafidi S, Riddle RC \& Wolfgang MJ 2017 Loss of hepatic mitochondrial long-chain fatty acid oxidation confers resistance to diet-induced obesity and glucose intolerance. Cell Reports 20 655-667. (https://doi.org/10.1016/j. celrep.2017.06.080)

Lee JY, Cho HK \& Kwon YH 2010 Palmitate induces insulin resistance without significant intracellular triglyceride accumulation in HepG2 cells. Metabolism 59 927-934. (https://doi.org/10.1016/j. metabol.2009.10.012)

Li M, Fan P \& Wang Y 2015 Lipidomics in health and diseases - beyond the analysis of lipids. Journal of Glycomics and Lipidomics 5126.

Li Z, Zhang H, Liu J, Liang CP, Li Y, Li Y, Teitelman G, Beyer T, Bui HH, Peake DA, et al. 2011 Reducing plasma membrane sphingomyelin increases insulin sensitivity. Molecular and Cellular Biology 31 4205-4218. (https://doi.org/10.1128/MCB.05893-11)

Liepinsh E, Makrecka-Kuka M, Makarova E, Volska K, Svalbe B, Sevostjanovs E, Grinberga S, Kuka J \& Dambrova M 2016 Decreased acylcarnitine content improves insulin sensitivity in experimental mice models of insulin resistance. Pharmacological Research 113 788-795. (https://doi.org/10.1016/j.phrs.2015.11.014)

Liepinsh E, Makrecka-Kuka M, Makarova E, Volska K, Vilks K, Sevostjanovs E, Antone U, Kuka J, Vilskersts R, Lola D, et al. 2017 Acute and long-term administration of palmitoylcarnitine induces muscle-specific insulin resistance in mice. BioFactors 43 718-730. (https://doi.org/10.1002/biof.1378)

Listenberger LL, Han X, Lewis SE, Cases S, Farese RV Jr, Ory DS \& Schaffer JE 2003 Triglyceride accumulation protects against fatty acid-induced lipotoxicity. PNAS 100 3077-3082. (https://doi. org/10.1073/pnas.0630588100)

Liu L, Zhang Y, Chen N, Shi X, Tsang B \& Yu YH 2007 Upregulation of myocellular DGAT1 augments triglyceride synthesis in skeletal muscle and protects against fat-induced insulin resistance. Journal of Clinical Investigation 117 1679-1689. (https://doi.org/10.1172/ JCI30565)

Longato L, Ripp K, Setshedi M, Dostalek M, Akhlaghi F, Branda M, Wands JR \& de la Monte SM 2012 Insulin resistance, ceramide accumulation, and endoplasmic reticulum stress in human chronic alcohol-related liver disease. Oxidative Medicine and Cellular Longevity 2012 479348. (https://doi.org/10.1155/2012/479348)

Lundsgaard A-M, Sjøberg KA, Høeg LD, Jeppesen J, Jordy AB, Serup AK, Fritzen AM, Pilegaard H, Myrmel LS, Madsen L, et al. 2017 Opposite regulation of insulin sensitivity by dietary lipid versus carbohydrate excess. Diabetes 66 2583-2595. (https://doi.org/10.2337/db17-0046)

Lung M, Shulga YV, Ivanova PT, Myers DS, Milne SB, Brown HA, Topham MK \& Epand RM 2009 Diacylglycerol kinase epsilon is selective for both acyl chains of phosphatidic acid or diacylglycerol. Journal of Biological Chemistry 284 31062-31073. (https://doi. org/10.1074/jbc.M109.050617)

Luukkonen PK, Zhou Y, Sädevirta S, Leivonen M, Arola J, Orešič M, Hyötyläinen T \& Yki-Järvinen H 2016 Hepatic ceramides dissociate steatosis and insulin resistance in patients with non-alcoholic fatty liver disease. Journal of Hepatology 64 1167-1175. (https://doi. org/10.1016/j.jhep.2016.01.002)

Lydic TA \& Goo YH 2018 Lipidomics unveils the complexity of the lipidome in metabolic diseases. Clinical and Translational Medicine $\mathbf{7}$ 4. (https://doi.org/10.1186/s40169-018-0182-9)

Madani S, Hichami A, Legrand A, Belleville J \& Khan NA 2001 Implication of acyl chain of diacylglycerols in activation of different isoforms of protein kinase C. FASEB Journal 15 2595-2601. (https:// doi.org/10.1096/fj.01-0753int)

Magkos F \& Mittendorfer B 2009 Stable isotope-labeled tracers for the investigation of fatty acid and triglyceride metabolism in humans in vivo Clinical Lipidology 4 215-230. (https://doi.org/10.2217/clp.09.9)

Magkos F, Su X, Bradley D, Fabbrini E, Conte C, Eagon JC, Varela JE, Brunt EM, Patterson BW \& Klein S 2012 Intrahepatic diacylglycerol content is associated with hepatic insulin resistance in obese subjects. Gastroenterology 142 1444-1446. (https://doi.org/10.1053/j. gastro.2012.03.003)

Manco M, Mingrone G, Greco AV, Capristo E, Gniuli D, De Gaetano A \& Gasbarrini G 2000 Insulin resistance directly correlates with increased saturated fatty acids in skeletal muscle triglycerides. Metabolism 49 220-224.

Mannerås-Holm L, Schönke M, Brozinick JT, Vetterli L, Bui HH, Sanders P, Nascimento EBM, Björnholm M, Chibalin AV \& Zierath JR 2017 Diacylglycerol kinase $\varepsilon$ deficiency preserves glucose tolerance and modulates lipid metabolism in obese mice. Journal of Lipid Research 58 907-915. (https://doi.org/10.1194/jlr.M074443)

Marignani PA, Epand RM \& Sebaldt RJ 1996 Acyl chain dependence of diacylglycerol activation of protein kinase $\mathrm{C}$ activity in vitro. Biochemical and Biophysical Research Communications 225 469-473. (https://doi.org/10.1006/bbrc.1996.1196)

McLaughlin T, Sherman A, Tsao P, Gonzalez O, Yee G, Lamendola C, Reaven GM \& Cushman SW 2007 Enhanced proportion of small adipose cells in insulin-resistant vs insulin-sensitive obese individuals implicates impaired adipogenesis. Diabetologia 50 1707-1715. (https://doi.org/10.1007/s00125-007-0708-y)

McLaughlin TM, Liu T, Yee G, Abbasi F, Lamendola C, Reaven GM, Tsao P, Cushman SW \& Sherman A 2010 Pioglitazone increases the proportion of small cells in human abdominal subcutaneous adipose tissue. Obesity 18 926-931. (https://doi.org/10.1038/oby.2009.380)

McLaughlin T, Lamendola C, Coghlan N, Liu TC, Lerner K, Sherman A \& Cushman SW 2014 Subcutaneous adipose cell size and distribution: relationship to insulin resistance and body fat. Obesity 22 673-680. (https://doi.org/10.1002/oby.20209)

Meikle PJ \& Summers SA 2017 Sphingolipids and phospholipids in insulin resistance and related metabolic disorders. Nature Reviews Endocrinology 13 79-91. (https://doi.org/10.1038/nrendo.2016.169)

Mesicek J, Lee H, Feldman T, Jiang X, Skobeleva A, Berdyshev EV, Haimovitz-Friedman A, Fuks Z \& Kolesnick R 2010 Ceramide synthases 2, 5, and 6 confer distinct roles in radiation-induced apoptosis in HeLa cells. Cellular Signalling 22 1300-1307. (https:// doi.org/10.1016/j.cellsig.2010.04.006)

Mihalik SJ, Goodpaster BH, Kelley DE, Chace DH, Vockley J, Toledo FG \& DeLany JP 2010 Increased levels of plasma acylcarnitines in obesity and type 2 diabetes and identification of a marker of glucolipotoxicity. Obesity 18 1695-1700. (https://doi.org/10.1038/ oby.2009.510)

MohammadTaghvaei N, Taheripak G, Taghikhani M \& Meshkani R 2012 Palmitate-induced PTP1B expression is mediated by ceramide-JNK and nuclear factor $\mathrm{\kappa B}(\mathrm{NF}-\mathrm{\kappa} \mathrm{B})$ activation. Cellular Signalling $\mathbf{2 4}$ 1964-1970. (https://doi.org/10.1016/j.cellsig.2012.04.019)

Monetti M, Levin MC, Watt MJ, Sajan MP, Marmor S, Hubbard BK, Stevens RD, Bain JR, Newgard CB, Farese RV Sr 2007 Dissociation of hepatic steatosis and insulin resistance in mice overexpressing DGAT in the liver. Cell Metabolism 6 69-78. (https://doi.org/10.1016/j. cmet.2007.05.005)

Montell E, Turini M, Marotta M, Roberts M, Noé V, Ciudad CJ, Macé K \& Gómez-Foix AM 2001 DAG accumulation from saturated fatty acids desensitises insulin stimulation of glucose uptake in muscle cells. American Journal of Endocrinology: Endocrinology and Metabolism 280 E229-E237. (https://doi.org/10.1152/ajpendo.2001.280.2.E229)

Montgomery MK \& Turner N 2015 Mitochondrial dysfunction and insulin resistance: an update. Endocrine Connections 4 R1-R15. (https://doi.org/10.1530/EC-14-0092)

Montgomery MK, Brown SH, Lim XY, Fiveash CE, Osborne B, Bentley NL, Braude JP, Mitchell TW, Coster AC, Don AS, et al. 2016 Regulation of glucose homeostasis and insulin action by ceramide acyl-chain length: a beneficial role for very long-chain sphingolipid species. Biochimica et Biophysica Acta 1861 1828-1839. (https://doi. org/10.1016/j.bbalip.2016.08.016)

Montgomery MK, Brown SH, Mitchell TW, Coster AC, Cooney GJ \& Turner N 2017 Association of muscle lipidomic profile with high-fat (c) 2019 Society for Endocrinology Published by Bioscientifica Ltd. Printed in Great Britain 
diet-induced insulin resistance across five mouse strains. Scientific Reports 7 13914. (https://doi.org/10.1038/s41598-017-14214-1)

Mootha VK, Lindgren CM, Eriksson KF, Subramanian A, Sihag S, Lehar J, Puigserver P, Carlsson E, Ridderstrale M, Laurila E, et al. 2003 PGC1alpha-responsive genes involved in oxidative phosphorylation are coordinately downregulated in human diabetes. Nature Genetics $\mathbf{3 4}$ 267-273. (https://doi.org/10.1038/ng1180)

Moraes-Vieira PM, Saghatelian A \& Kahn BB 2016 GLUT4 expression in adipocytes regulates de novo lipogenesis and levels of a novel class of lipids with antidiabetic and anti-inflammatory effects. Diabetes $\mathbf{6 5}$ 1808-1815. (https://doi.org/10.2337/db16-0221)

Mullen TD, Spassieva S, Jenkins RW, Kitatani K, Bielawski J, Hannun YA \& Obeid LM 2011 Selective knockdown of ceramide synthases reveals complex interregulation of sphingolipid metabolism. Journal of Lipid Research 52 68-77. (https://doi.org/10.1194/jlr.M009142)

Muoio DM, Noland RC, Kovalik JP, Seiler SE, Davies MN, DeBalsi KL, Ilkayeva OR, Stevens RD, Kheterpal I, Zhang J, et al. 2012 Musclespecific deletion of carnitine acetyltransferase compromises glucose tolerance and metabolic flexibility. Cell Metabolism 15 764-77. (https://doi.org/10.1016/j.cmet.2012.04.005)

Nakano T, Matsui H, Tanaka T, Hozumi Y, Iseki K, Kawamae K \& Goto K 2016 Arachidonoyl-specific diacylglycerol kinase $\varepsilon$ and the endoplasmic reticulum. Frontiers in Cell and Developmental Biology 4 132. (https://doi.org/10.3389/fcell.2016.00132)

Neschen S, Morino K, Hammond LE, Zhang D, Liu ZX, Romanelli AJ, Cline GW, Pongratz RL, Zhang XM, Choi CS, et al. 2005 Prevention of hepatic steatosis and hepatic insulin resistance in mitochondrial acyl-CoA:glycerol-sn-3-phosphate acyltransferase 1 knockout mice. Cell Metabolism 2 55-65. (https://doi.org/10.1016/j. cmet.2005.06.006)

Newsom SA, Brozinick JT, Kiseljak-Vassiliades K, Strauss AN, Bacon SD, Kerege AA, Bui HH, Sanders P, Siddall P, Wei T, et al. 2016 Skeletal muscle phosphatidylcholine and phosphatidylethanolamine are related to insulin sensitivity and respond to acute exercise in humans. Journal of Applied Physiology 120 1355-1363. (https://doi. org/10.1152/japplphysiol.00664.2015)

Nolan CJ, Madiraju MS, Delghingaro-Augusto V, Peyot ML \& Prentki M 2006 Fatty acid signaling in the $\beta$-cell and insulin secretion. Diabetes 55 S16-S23. (https://doi.org/10.2337/db06-S003)

Nowotny B, Zahiragic L, Krog D, Nowotny PJ, Herder C, Carstensen M, Yoshimura T, Szendroedi J, Phielix E, Schadewaldt P, et al. 2013 Mechanisms underlying the onset of oral lipid-induced skeletal muscle insulin resistance in humans. Diabetes 62 2240-2248. (https://doi.org/10.2337/db12-1179)

Oakes ND, Bell KS, Furler SM, Camilleri S, Saha AK, Ruderman NB, Chisholm DJ \& Kraegen EW 1997a Diet-induced muscle insulin resistance in rats is ameliorated by acute dietary lipid withdrawal or a single bout of exercise. Diabetes 46 2022-2028. (https://doi. org/10.2337/diab.46.12.2022)

Oakes ND, Cooney GJ, Camilleri S, Chisholm DJ \& Kraegen EW 1997b Mechanisms of liver and muscle insulin resistance induced by chronic high-fat feeding. Diabetes 46 1768-1774. (https://doi. org/10.2337/diab.46.11.1768)

Pan DA, Lillioja S, Milner MR, Kriketos AD, Baur LA, Bogardus C \& Storlien LH 1995 Skeletal muscle membrane lipid composition is related to adiposity and insulin action. Journal of Clinical Investigation 96 2802-2808. (https://doi.org/10.1172/JCI118350)

Pan DA, Lillioja S, Kriketos AD, Milner MR, Baur LA, Bogardus C, Jenkins AB \& Storlien LH 1997 Skeletal muscle triglyceride levels are inversely related to insulin action. Diabetes 46 983-988. (https://doi. org/10.2337/diab.46.6.983)

Park JW, Park WJ, Kuperman Y, Boura-Halfon S, Pewzner-Jung Y \& Futerman AH 2013 Ablation of very long acyl chain sphingolipids causes hepatic insulin resistance in mice due to altered detergentresistant membranes. Hepatology 57 525-532. (https://doi. org/10.1002/hep.26015)
Patti ME, Butte AJ, Crunkhorn S, Cusi K, Berria R, Kashyap S, Miyazaki Y, Kohane I, Costello M, Saccone R, et al. 2003 Coordinated reduction of genes of oxidative metabolism in humans with insulin resistance and diabetes: potential role of PGC1 and NRF1. PNAS $\mathbf{1 0 0}$ 8466-8471. (https://doi.org/10.1073/pnas.1032913100)

Perreault L, Newsom SA, Strauss A, Kerege A, Kahn DE, Harrison KA, Snell-Bergeon JK, Nemkov T, D’Alessandro A, Jackman MR, et al. 2018 Intracellular localisation of diacylglycerols and sphingolipids influences insulin sensitivity and mitochondrial function in human skeletal muscle. JCI Insight 3 e96805. (https://doi.org/10.1172/jci. insight.96805)

Petersen KF, Befroy D, Dufour S, Dziura J, Ariyan C, Rothman DL, DiPietro L, Cline GW \& Shulman GI 2003 Mitochondrial dysfunction in the elderly: possible role in insulin resistance. Science 300 1140-1142. (https://doi.org/10.1126/science.1082889)

Petersen MC \& Shulman GI 2017 Roles of diacylglycerols and ceramides in hepatic insulin resistance. Trends in Pharmacological Sciences $\mathbf{3 8}$ 649-665. (https://doi.org/10.1016/j.tips.2017.04.004)

Petersen MC, Madiraju AK, Gassaway BM, Marcel M, Nasiri AR, Butrico G, Marcucci MJ, Zhang D, Abulizi A, Zhang XM, et al. 2016 Insulin receptor Thr1160 phosphorylation mediates lipid-induced hepatic insulin resistance. Journal of Clinical Investigation 126 4361-4371. (https://doi.org/10.1172/JCI86013)

Pewzner-Jung Y, Park H, Laviad EL, Silva LC, Lahiri S, Stiban J, ErezRoman R, Brügger B, Sachsenheimer T, Wieland F, et al. 2010 A critical role for ceramide synthase 2 in liver homeostasis: I. alterations in lipid metabolic pathways. Journal of Biological Chemistry 285 10902-10910. (https://doi.org/10.1074/jbc.M109.077594)

Pickersgill L, Litherland GJ, Greenberg AS, Walker M \& Yeaman SJ 2007 Key role for ceramides in mediating insulin resistance in human muscle cells. Journal of Biological Chemistry 282 12583-12589. (https://doi.org/10.1074/jbc.M611157200)

Poitout V \& Robertson RP 2008 Glucolipotoxicity: fuel excess and $\beta$-cell dysfunction. Endocrine Reviews 29 351-366. (https://doi.org/10.1210/ er.2007-0023)

Popp-Snijders C, Schouten JA, Heine RJ, van der Meer J \& van der Veen EA 1987 Dietary supplementation of omega-3 polyunsaturated fatty acids improves insulin sensitivity in non-insulin dependent diabetes. Diabetes Research 4 141-147.

Pospisilik JA, Knauf C, Joza N, Benit P, Orthofer M, Cani PD, Ebersberger I, Nakashima T, Sarao R, Neely G, et al. 2007 Targeted deletion of AIF decreases mitochondrial oxidative phosphorylation and protects from obesity and diabetes. Cell 131 476-491. (https:// doi.org/10.1016/j.cell.2007.08.047)

Powell DJ, Hajduch E, Kular G \& Hundal HS 2003 Ceramide disables 3-phosphoinositide binding to the pleckstrin homology domain of protein kinase B (PKB)/Akt by a PKC -dependent mechanism. Molecular and Cellular Biology 23 7794-7808. (https://doi. org/10.1128/MCB.23.21.7794-7808.2003)

Raichur S, Wang ST, Chan PW, Li Y, Ching J, Chaurasia B, Dogra S, Öhman MK, Takeda K, Sugii S, et al. 2014 CerS2 haploinsufficiency inhibits beta-oxidation and confers susceptibility to diet-induced steatohepatitis and insulin resistance. Cell Metabolism 20 687-695. (https://doi.org/10.1016/j.cmet.2014.09.015)

Rando RR \& Young N 1984 The stereospecific activation of protein kinase C. Biochemical and Biophysical Research Communications 122 818-823. (https://doi.org/10.1016/S0006-291X(84)80107-2)

Ritov VB, Menshikova EV, He J, Ferrell RE, Goodpaster BH \& Kelley DE 2005 Deficiency of subsarcolemmal mitochondria in obesity and type 2 diabetes. Diabetes 54 8-14. (https://doi.org/10.2337/ diabetes.54.1.8)

Rocha M, Diaz-Morales N, Rovira-Llopis S, Escribano-Lopez I, Bañuls C, Hernandez-Mijares A, Diamanti-Kandarakis E \& Victor VM 2016 Mitochondrial dysfunction and endoplasmic reticulum stress in diabetes. Current Pharmaceutical Design 22 2640-2649. (https://doi. org/10.2174/1381612822666160209152033) 
Roomp K, Kristinsson H, Schvartz D, Ubhayasekera K, Sargsyan E, Manukyan L, Chowdhury A, Manell H, Satagopam V, Groebe K, et al. 2017 Combined lipidomic and proteomic analysis of isolated human islets exposed to palmitate reveals time-dependent changes in insulin secretion and lipid metabolism. PLOS ONE 12 e0176391. (https://doi.org/10.1371/journal.pone.0176391)

Saheki Y, Bian X, Schauder CM, Sawaki Y, Surma MA, Klose C, Pincet F, Reinisch KM \& De Camilli P 2016 Control of plasma membrane lipid homeostasis by the extended synaptotagmins. Nature Cell Biology 18 504-515. (https://doi.org/10.1038/ncb3339)

Sakai H, Kado S, Taketomi A \& Sakane F 2014 Diacylglycerol kinase $\delta$ phosphorylates phosphatidylcholine-specific phospholipase C-dependent, palmitic acid-containing diacylglycerol species in response to high glucose levels. Journal of Biological Chemistry 289 26607-26617. (https://doi.org/10.1074/jbc.M114.590950)

Salinas M, López-Valdaliso R, Martín D, Alvarez A \& Cuadrado A 2000 Inhibition of PKB/Akt1 by C2-ceramide involves activation of ceramide-activated protein phosphatase in PC12 Cells. Molecular and Cellular Neuroscience 15 156-169. (https://doi.org/10.1006/ mcne.1999.0813)

Saltiel AR \& Kahn CR 2001 Insulin signalling and the regulation of glucose and lipid metabolism. Nature 414 799-806. (https://doi. org/10.1038/414799a)

Samuel VT \& Shulman GI 2012 Mechanisms for insulin resistance: common threads and missing links. Cell 148 852-871. (https://doi. org/10.1016/j.cell.2012.02.017)

Samuel VT, Liu ZX, Qu X, Elder BD, Bilz S, Befroy D, Romanelli AJ \& Shulman GI 2004 Mechanism of hepatic insulin resistance in nonalcoholic fatty liver disease. Journal of Biological Chemistry 279 32345-32353. (https://doi.org/10.1074/jbc.M313478200)

Samuel VT, Liu ZX, Wang A, Beddow SA, Geisler JG, Kahn M, Zhang XM, Monia BP, Bhanot S \& Shulman GI 2007 Inhibition of protein kinase $\mathrm{C} \varepsilon$ prevents hepatic insulin resistance in nonalcoholic fatty liver disease. Journal of Clinical Investigation $\mathbf{1 1 7}$ 739-745. (https://doi.org/10.1172/JCI30400)

Sassa T, Ohno Y, Suzuki S, Nomura T, Nishioka C, Kashiwagi T, Hirayama T, Akiyama M, Taguchi R, Shimizu H, et al. 2013 Impaired epidermal permeability barrier in mice lacking elovl1, the gene responsible for very-long-chain fatty acid production. Molecular and Cellular Biology 33 2787-2796. (https://doi.org/10.1128/MCB.00192-13)

Sathyanarayana P, Barthwal MK, Kundu CN, Lane ME, Bergmann A, Tzivion G \& Rana A 2002 Activation of the Drosophilia MLK by ceramide reveals TNF-alpha and ceramide as agonists of mammalian MLK3. Molecular Cell 10 1527-1533. (https://doi.org/10.1016/S10972765(02)00734-7)

Schenk S \& Horowitz JF 2007 Acute exercise increases triglyceride synthesis in skeletal muscle and prevents fatty acid-induced insulin resistance. Journal of Clinical Investigation 117 1690-1698. (https:// doi.org/10.1172/JCI30566)

Schmitz-Peiffer C, Laybutt DR, Burchfield JG, Gurisik E, Narasimhan S, Mitchell CJ, Pedersen DJ, Braun U, Cooney GJ, Leitges M, et al. 2007 Inhibition of $\mathrm{PKC} \varepsilon$ improves glucose-stimulated insulin secretion and reduces insulin clearance. Cell Metabolism 6 320-328. (https:// doi.org/10.1016/j.cmet.2007.08.012)

Selathurai A, Kowalski GM, Burch ML, Sepulveda P, Risis S, LeeYoung RS, Lamon S, Meikle PJ, Genders AJ, McGee SL, et al. 2015 The CDP-ethanolamine pathway regulates skeletal muscle diacylglycerol content and mitochondrial biogenesis without altering insulin sensitivity. Cell Metabolism 21 718-730. (https://doi. org/10.1016/j.cmet.2015.04.001)

Semple RK, Sleigh A, Murgatroyd PR, Adams CA, Bluck L, Jackson S, Vottero A, Kanabar D, Charlton-Menys V, Durrington P, et al. 2009 Postreceptor insulin resistance contributes to human dyslipidemia and hepatic steatosis. Journal of Clinical Investigation 119 315-322. (https://doi.org/10.1172/JCI37432)

Serup AK, Alsted TJ, Jordy AB, Schjerling P, Holm C \& Kiens B 2016 Partial disruption of lipolysis increases postexercise insulin sensitivity in skeletal muscle despite accumulation of DAG. Diabetes $\mathbf{6 5}$ 2932-2942. (https://doi.org/10.2337/db16-0655)

Shepherd SO, Cocks M, Meikle PJ, Mellett NA, Ranasinghe AM, Barker TA, Wagenmakers AJM \& Shaw CS 2017 Lipid droplet remodelling and reduced muscle ceramides following sprint interval and moderate-intensity continuous exercise training in obese males. International Journal of Obesity 41 1745-1754. (https://doi. org/10.1038/ijo.2017.170)

Shevchenko A \& Simons K 2010 Lipidomics: coming to grips with lipid diversity. Nature Reviews Molecular Cell Biology 11 593-598. (https:// doi.org/10.1038/nrm2934)

Shulga YV, Topham MK \& Epand RM 2011 Substrate specificity of diacylglycerol kinase-epsilon and the phosphatidylinositol cycle. FEBS Letters 585 4025-4028. (https://doi.org/10.1016/j. febslet.2011.11.016)

Silva LC, Ben David O, Pewzner-Jung Y, Laviad EL, Stiban J, Bandyopadhyay S, Merrill AH Jr, Prieto M \& Futerman AH 2012 Ablation of ceramide synthase 2 strongly affects biophysical properties of membranes. Journal of Lipid Research $\mathbf{5 3} 430-436$. (https://doi.org/10.1194/jlr.M022715)

Skovbro M, Baranowski M, Skov-Jensen C, Flint A, Dela F, Gorski J \& Helge JW 2008 Human skeletal muscle ceramide content is not a major factor in muscle insulin sensitivity. Diabetologia $\mathbf{5 1}$ 1253-1260. (https://doi.org/10.1007/s00125-008-1014-z)

Smith BK, Holloway GP, Reza-Lopez S, Jeram SM, Kang JX \& Ma DW 2010 A decreased n-6/n-3 ratio in the fat- 1 mouse is associated with improved glucose tolerance. Applied Physiology, Nutrition, and Metabolism 35 699-706. (https://doi.org/10.1139/H10-066)

Stephens FB, Mendis B, Shannon CE, Cooper S, Ortori CA, Barrett DA, Mansell P \& Tzintzas K 2014 Fish oil omega-3 fatty acids partially prevent lipid-induced insulin resistance in human skeletal muscle without limiting acylcarnitine accumulation. Clinical Science $\mathbf{1 2 7}$ 315-322. (https://doi.org/10.1042/CS20140031)

Stiban J \& Perera M 2015 Very long chain ceramides interfere with C16ceramide-induced channel formation: a plausible mechanism for regulating the initiation of intrinsic apoptosis. Biochimica et Biophysica Acta 1848 561-567. (https://doi.org/10.1016/j. bbamem.2014.11.018)

Stöckli J, Fisher-Wellman KH, Chaudhuri R, Zeng XY, Fazakerley DJ, Meoli CC, Thomas KC, Hoffman NJ, Mangiafico SP, Xirouchaki CE, et al. 2017 Metabolomic analysis of insulin resistance across different mouse strains and diets. Journal of Biological Chemistry 292 19135-19145. (https://doi.org/10.1074/jbc.M117.818351)

Storlien LH, Jenkins AB, Chisholm DJ, Pascoe WS, Khouri S \& Kraegen EW 1991 Influence of dietary fat composition on development of insulin resistance in rats. Relationship to muscle triglyceride and omega-3 fatty acids in muscle phospholipid. Diabetes 40 280-289.

Straczkowski M, Kowalska I, Nikolajuk A, Dzienis-Straczkowska S, Kinalska I, Baranowski M, Zendzian-Piotrowska M, Brzezinska Z \& Gorski J 2004 Relationship between insulin sensitivity and sphingomyelin signaling pathway in human skeletal muscle. Diabetes 53 1215-1221. (https://doi.org/10.2337/diabetes.53.5.1215)

Stratford S, DeWald DB \& Summers SA 2001 Ceramide dissociates 3'-phosphoinositide production from pleckstrin homology domain translocation. Biochemical Journal 354 359-368. (https://doi. org/10.1042/bj3540359)

Stratford S, Hoehn KL, Liu F \& Summers SA 2004 Regulation of insulin action by ceramide: dual mechanisms linking ceramide accumulation to the inhibition of Akt/protein kinase B. Journal of Biological Chemistry 279 36608-36615. (https://doi.org/10.1074/jbc. M406499200)

Su X, Magkos F, Zhou D, Eagon JC, Fabbrini E, Okunade AL \& Klein S 2015 Adipose tissue monomethyl branched-chain fatty acids and insulin sensitivity: effects of obesity and weight loss. Obesity $\mathbf{2 3}$ 329-334. (https://doi.org/10.1002/oby.20923)

Sugimoto M, Shimizu Y, Zhao S, Ukon N, Nishijima K, Wakabayashi M, Yoshioka T, Higashino K, Numata Y, Okuda T, et al. 2016 
Characterisation of the role of sphingomyelin synthase 2 in glucose metabolism in whole-body and peripheral tissues in mice. Biochimica et Biophysica Acta 1861 688-702. (https://doi.org/10.1016/j. bbalip.2016.04.019)

Summers SA 2006 Ceramides in insulin resistance and lipotoxicity. Progress in Lipid Research 45 42-72. (https://doi.org/10.1016/j. plipres.2005.11.002)

Szendroedi J, Yoshimura T, Phielix E, Koliaki C, Marcucci M, Zhang D, Jelenik T, Müller J, Herder C, Nowotny P, et al. 2014 Role of diacylglycerol activation of PKCO in lipid-induced muscle insulin resistance in humans. PNAS 111 9597-9602. (https://doi. org/10.1073/pnas.1409229111)

Tagami S, Inokuchi JJ, Kabayama K, Yoshimura H, Kitamura F, Uemura S, Ogawa C, Ishii A, Saito M, Ohtsuka Y, et al. 2002 Ganglioside GM3 participates in the pathological conditions of insulin resistance. Journal of Biological Chemistry 277 3085-3092. (https://doi. org/10.1074/jbc.M103705200)

Takai Y, Kishimoto A, Kikkawa U, Mori T \& Nishizuka Y 2012 Unsaturated diacylglycerol as a possible messenger for the activation of calcium-activated, phospholipid-dependent protein kinase system. 1979. Biochemical and Biophysical Research Communications 425 571-577. (https://doi.org/10.1016/j.bbrc.2012.08.026)

Taniguchi CM, Emanuelli B \& Kahn CR 2006 Critical nodes in signalling pathways: insights into insulin action. Nature Reviews Molecular Cell Biology 7 85-96. (https://doi.org/10.1038/nrm1837)

Ter Horst KW, Gilijamse PW, Versteeg RI, Ackermans MT, Nederveen AJ, la Fleur SE, Romijn JA, Nieuwdorp M, Zhang D, Samuel VT, et al. 2017 Hepatic diacylglycerol-associated protein kinase $\mathrm{C} \varepsilon$ translocation links hepatic steatosis to hepatic insulin resistance in humans. Cell Reports 19 1997-2004. (https://doi.org/10.1016/j. celrep.2017.05.035)

Teruel T, Hernandez R \& Lorenzo M 2001 Ceramide mediates insulin resistance by tumor necrosis factor- $\alpha$ in brown adipocytes by maintaining Akt in an inactive dephosphorylated state. Diabetes $\mathbf{5 0}$ 2563-2571. (https://doi.org/10.2337/diabetes.50.11.2563)

Thompson AL \& Cooney GJ 2000 Acyl-CoA inhibition of hexokinase in rat and human skeletal muscle is a potential mechanism of lipidinduced insulin resistance. Diabetes 49 1761-1765. (https://doi. org/10.2337/diabetes.49.11.1761)

Tidhar R \& Futerman AH 2013 The complexity of sphingolipid biosynthesis in the endoplasmic reticulum. Biochimica et Biophysica Acta 1833 2511-2518. (https://doi.org/10.1016/j. bbamcr.2013.04.010)

Tidhar R, Ben-Dor S, Wang E, Kelly S, Merrill AH \& Futerman AH 2012 Acyl chain specificity of ceramide synthases is determined within a region of 150 residues in the Tram-Lag-CLN8 (TLC) domain. Journal of Biological Chemistry 287 3197-3206. (https://doi.org/10.1074/jbc. M111.280271)

Tiganis T 2011 Reactive oxygen species and insulin resistance: the good, the bad and the ugly. Trends in Pharmacological Sciences 32 82-89. (https://doi.org/10.1016/j.tips.2010.11.006)

Tippet PS \& Neet KE 1982a Specific inhibition of glucokinase by long chain acyl coenzymes A below the critical micelle concentration. Journal of Biological Chemistry 257 12839-12845.

Tippet PS \& Neet KE 1982b An allosteric model for the inhibition of glucokinase by long chain acyl coenzyme A. Journal of Biological Chemistry 257 12846-12852.

Tonks KT, Coster AC, Christopher MJ, Chaudhuri R, Xu A, GagnonBartsch J, Chisholm DJ, James DE, Meikle PJ, Greenfield JR, et al. 2016 Skeletal muscle and plasma lipidomic signatures of insulin resistance and overweight/obesity in humans. Obesity 24 908-916. (https://doi.org/10.1002/oby.21448)

Triebl A, Hartler J, Trötzmüller M \& Köfeler HC 2017 Lipidomics: prospects from a technological perspective. Biochimica et Biophysica Acta 1862 740-746. (https://doi.org/10.1016/j.bbalip.2017.03.004)

Tsintzas K, Chokkalingam K, Jewell K, Norton L, Macdonald IA \& Constantin-Teodosiu D 2007 Elevated free fatty acids attenuate the insulin-induced suppression of PDK4 gene expression in human skeletal muscle: potential role of intramuscular long-chain acylcoenzyme A. Journal of Clinical Endocrinology and Metabolism 92 3967-3972. (https://doi.org/10.1210/jc.2007-1104)

Turinsky J, Bayly BP \& O'Sullivan DM 1990 1,2-Diacylglycerol and ceramide levels in rat skeletal muscle and liver in vivo. Journal of Biological Chemistry 265 7933-7938.

Turner N, Bruce CR, Beale SM, Hoehn KL, So T, Rolph MS \& Cooney GJ 2007 Excess lipid availability increases mitochondrial fatty acid oxidative capacity in muscle: evidence against a role for reduced fatty acid oxidation in lipid-induced insulin resistance in rodents. Diabetes 56 2085-2092. (https://doi.org/10.2337/db07-0093)

Turner N, Kowalski GM, Leslie SJ, Risis S, Yang C, Lee-Young RS, Babb JR, Meikle PJ, Lancaster GI, Henstridge DC, et al. 2013 Distinct patterns of tissue-specific lipid accumulation during the induction of insulin resistance in mice by high-fat feeding. Diabetologia $\mathbf{5 6}$ 1638-1648. (https://doi.org/10.1007/s00125-013-2913-1)

Turpin SM, Hoy AJ, Brown RD, Rudaz CG, Honeyman J, Matzaris M \& Watt MJ 2011 Adipose triacylglycerol lipase is a major regulator of hepatic lipid metabolism but not insulin sensitivity in mice. Diabetologia 54 146-156. (https://doi.org/10.1007/s00125-010-1895-5)

Turpin SM, Nicholls HT, Willmes DM, Mourier A, Brodesser S, Wunderlich CM, Mauer J, Xu E, Hammerschmidt P, Brönneke HS, et al. 2014 Obesity-induced CerS6-dependent C16:0 ceramide production promotes weight gain and glucose intolerance. Cell Metabolism 20 678-686. (https://doi.org/10.1016/j.cmet.2014.08.002)

Ukropcova B, McNeil M, Sereda O, de Jonge L, Xie H, Bray GA \& Smith SR 2005 Dynamic changes in fat oxidation in human primary myocytes mirror metabolic characteristics of the donor. Journal of Clinical Investigation 115 1934-1941. (https://doi.org/10.1172/ JCI24332)

Umpleby AM 2015 Tracing lipid metabolism: the value of stable isotopes Journal of Endocrinology 226 G1-G10. (https://doi.org/10.1530/JOE14-0610)

Ussher JR, Koves TR, Cadete VJ, Zhang L, Jaswal JS, Swyrd SJ, Lopaschuk DG, Proctor SD, Keung W, Muoio DM, et al. 2010 Inhibition of de novo ceramide synthesis reverses diet-induced insulin resistance and enhances whole-body oxygen consumption. Diabetes 59 2453-2464. (https://doi.org/10.2337/db09-1293)

van Hees AM, Jans A, Hul GB, Roche HM, Saris WH \& Blaak EE 2011 Skeletal muscle fatty acid handling in insulin resistant men. Obesity 19 1350-1359. (https://doi.org/10.1038/oby.2011.10)

Van Hove JL, Zhang W, Kahler SG, Roe CR, Chen YT, Terada N, Chace DH, Iafolla AK, Sing JH \& Millington DS 1993 Medium-chain acyl-CoA dehydrogenase (MCAD) deficiency: diagnosis by acylcarnitine analysis in blood. American Journal of Human Genetics 52 958-966.

Visser ME, Lammers NM, Nederveen AJ, van der Graaf M, Heerschap A Ackermans MT, Sauerwein HP, Stroes ES \& Serlie MJ 2011 Hepatic steatosis does not cause insulin resistance in people with familial hypobetalipoproteinaemia. Diabetologia 54 2113-2121. (https://doi. org/10.1007/s00125-011-2157-x)

Wakelam MJ 1998 Diacylglycerol-when is it an intracellular messenger? Biochimica et Biophysica Acta 1436 117-126. (https://doi.org/10.1016/ S0005-2760(98)00123-4)

Wang H, Knaub LA, Jensen DR, Young Jung D, Hong EG, Ko HJ, Coates AM, Goldberg IJ, de la Houssaye BA, Janssen RC, et al. 2009 Skeletal muscle-specific deletion of lipoprotein lipase enhances insulin signaling in skeletal muscle but causes insulin resistance in liver and other tissues. Diabetes 58 116-124. (https://doi. org/10.2337/db07-1839)

Warshauer JT, Lopez X, Gordillo R, Hicks J, Holland WL, Anuwe E, Blankfard MB, Scherer PE \& Lingvay I 2015 Effect of pioglitazone on plasma ceramides in adults with metabolic syndrome. Diabetes/ Metabolism Research and Reviews 31 734-744. (https://doi. org/10.1002/dmrr.2662)

Wegner MS, Schiffmann S, Parnham MJ, Geisslinger G \& Grosch S 2016 The enigma of ceramide synthase regulation in mammalian cells. 
Progress in Lipid Research 63 93-119. (https://doi.org/10.1016/j. plipres.2016.03.006)

Weyer C, Foley JE, Bogardus C, Tataranni PA \& Pratley RE 2000 Enlarged subcutaneous abdominal adipocyte size, but not obesity itself, predicts type II diabetes independent of insulin resistance. Diabetologia 43 1498-1506. (https://doi.org/10.1007/s001250051560)

Wititsuwannakul D \& Kim KH 1977 Mechanism of palmityl coenzyme A inhibition of liver glycogen synthase. Journal of Biological Chemistry 252 7812-7817.

Wolf M, Chen S, Zhao X, Scheler M, Irmler M, Staiger H, Beckers J, de Angelis MH, Fritsche A, Häring HU, et al. 2013 Production and release of acylcarnitines by primary myotubes reflect the differences in fasting fat oxidation of the donors. Journal of Clinical Endocrinology and Metabolism 98 E1137-E1142. (https://doi.org/10.1210/jc.20123976)

Wredenberg A, Freyer C, Sandström ME, Katz A, Wibom R, Westerblad H \& Larsson NG 2006 Respiratory chain dysfunction in skeletal muscle does not cause insulin resistance. Biochemical and Biophysical Research Communications 350 202-207. (https://doi.org/10.1016/j. bbrc.2006.09.029)

Wright LE, Brandon AE, Hoy AJ, Forsberg GB, Lelliott CJ, Reznick J, Löfgren L, Oscarsson J, Strömstedt M, Cooney GJ, et al. 2011 Amelioration of lipid-induced insulin resistance in rat skeletal muscle by overexpression on $P g C-1 \beta$ involves reductions in longchain acyl-CoA levels and oxidative stress. Diabetologia $\mathbf{5 4}$ 1417-1426. (https://doi.org/10.1007/s00125-011-2068-x)

Wuttke A, Idevall-Hagren O \& Tengholm A 2013 P2Y 1 receptordependent diacylglycerol signalling microdomains in $\beta$ cells promote insulin secretion. FASEB Journal 27 1610-1620. (https://doi. org/10.1096/fj.12-221499)

Xia JY, Holland WL, Kusminski CM, Sun K, Sharma AX, Pearson MJ, Sifuentes AJ, McDonald JG, Gordillo R \& Scherer PE 2015 Targeted induction of ceramide degradation leads to improved systemic metabolism and reduced hepatic steatosis. Cell Metabolism 22 266-278. (https://doi.org/10.1016/j.cmet.2015.06.007)

Xiang L, Wei J, Tian XY, Wang B, Chan W, Li S, Tang Z, Zhang H, Cheang WS, Zhao Q et al. 2017 Comprehensive analysis of acylcarnitine species in $d b / d b$ mouse using a novel method of highresolution parallel reaction monitoring reveals widespread metabolic dysfunction induced by diabetes. Analytical Chemistry $\mathbf{8 9}$ 10368-10375. (https://doi.org/10.1021/acs.analchem.7b02283)

Xie P, Kadegowda AKG, Ma Y, Guo F, Han X, Wang M, Groban L, Xue B, Shi H, Li H, et al. 2015 Muscle-specific deletion of comparative gene identification-58 (CGI-58) causes muscle steatosis but improves insulin sensitivity in male mice. Endocrinology 156 1648-1658. (https://doi.org/10.1210/en.2014-1892)

Yamaji T, Horie A, Tachida Y, Sakuma C, Suzuki Y, Kushi Y \& Hanada K 2016 Role of intracellular lipid logistics in the preferential usage of very long chain-ceramides in glucosylceramide. International Journal of Molecular Sciences 17 1761. (https://doi.org/10.3390/ijms17101761)

Yamashita T, Hashiramoto A, Haluzik M, Mizukami H, Beck S, Norton A, Kono M, Tsuji S, Daniotti JL, Werth N, et al. 2003 Enhanced insulin sensitivity in mice lacking ganglioside GM3. PNAS 100 3445-3449. (https://doi.org/10.1073/pnas.0635898100)

Yang G, Badeanlou L, Bielawski J, Roberts AJ, Hannun YA \& Samad F 2009 Central role of ceramide biosynthesis in body weight regulation, energy metabolism, and the metabolic syndrome.
American Journal of Physiology: Endocrinology and Metabolism 297 E211-E224. (https://doi.org/10.1152/ajpendo.91014.2008)

Yang X, Jansson PA, Nagaev I, Jack MM, Carvalho E, Sunnerhagen KS, Cam MC, Cushman SW \& Smith U 2004 Evidence of impaired adipogenesis in insulin resistance. Biochemical and Biophysical Research Communications 317 1045-1051. (https://doi.org/10.1016/j. bbrc.2004.03.152)

Yore MM, Syed I, Moraes-Vieira PM, Zhang T, Herman MA, Homan E, Patel RT, Lee J, Chen S, Peroni OD, et al. 2014 Discovery of a class of endogenous mammalian lipids with anti-diabetic and antiinflammatory effects. Cell 159 318-332. (https://doi.org/10.1016/j. cell.2014.09.035)

Yorek M, Leeney E, Dunlap J \& Ginsberg B 1989 Effect of fatty acid composition on insulin and IGF-I binding in retinoblastoma cells. Investigative Ophthalmology and Visual Science 30 2087-2092.

You L, Zhang B \& Tang YJ 2014 Application of stable isotope-assisted metabolomics for cell metabolism studies. Metabolites 4 142-165. (https://doi.org/10.3390/metabo4020142)

Yu C, Chen Y, Cline GW, Zhang D, Zong H, Wang Y, Bergeron R, Kim JK, Cushman SW, Cooney GJ, et al. 2002 Mechanism by which fatty acids inhibit insulin activation of insulin receptor substrate-1 (IRS-1)-associated phosphatidylinositol 3-kinase activity in muscle. Journal of Biological Chemistry 277 50230-50236. (https://doi. org/10.1074/jbc.M200958200)

Yurlova L, Kahya N, Aggarwal S, Kaiser HJ, Chiantia S, Bakhti M, Pewzner-Jung Y, Ben-David O, Futerman AH, Brügger B, et al. 2011 Self-segregation of myelin membrane lipids in model membranes. Biophysical Journal 101 2713-2720. (https://doi.org/10.1016/j. bpj.2011.10.026)

Zabielski P, Blachnio-Zabielska AU, Wójcik B, Chabowski A \& Górski J 2017 Effect of plasma free fatty acid supply on the rate of ceramide synthesis in different muscle types in the rat. PLOS ONE $\mathbf{1 2}$ e0187136. (https://doi.org/10.1371/journal.pone.0187136)

Zhang C, Li J, Lan L \& Cheng JX 2017 Quantification of lipid metabolism in living cells through the dynamics of lipid droplets measured by stimulated Raman scattering imaging. Analytical Chemistry 89 4502-4507. (https://doi.org/10.1021/acs. analchem.6b04699)

Zhang D, Christianson J, Liu ZX, Tian L, Choi CS, Neschen S, Dong J, Wood PA \& Shulman GI 2010 Resistance to high-fat diet-induced obesity and insulin resistance in mice with very long-chain acyl-CoA dehydrogenase deficiency. Cell Metabolism 11 402-411. (https://doi. org/10.1016/j.cmet.2010.03.012)

Zhang D, Liu ZX, Choi CS, Tian L, Kibbey R, Dong J, Cline GW, Wood PA \& Shulman GI 2007 Mitochondrial dysfunction due to long-chain Acyl-CoA dehydrogenase deficiency causes hepatic steatosis and hepatic insulin resistance. PNAS 104 17075-17080. (https://doi.org/10.1073/pnas.0707060104)

Zhao H, Przybylska M, Wu IH, Zhang J, Siegel C, Komarnitsky S, Yew NS \& Cheng SH 2007 Inhibiting glycosphingolipid synthesis improves glycemic control and insulin sensitivity in animal models of type 2 diabetes. Diabetes 56 1210-1218. (https://doi.org/10.2337/db060719)

Zinda MJ, Vlahos CJ \& Lai MT 2001 Ceramide induces the dephosphorylation and inhibition of constitutively activated Akt in PTEN negative U87MG cells. Biochemical and Biophysical Research Communications 280 1107-1115. (https://doi.org/10.1006/ bbrc.2000.4248)

Received in final form 4 July 2018

Accepted 31 July 2018

Accepted Preprint published online 1 August 2018 https://jme.bioscientifica.com https://doi.org/10.1530/JME-18-0023
(C) 2019 Society for Endocrinology Published by Bioscientifica Ltd. Printed in Great Britain 